\title{
LOPE DE VEGA SEGÚN LOS INICIADORES CIENTÍFICOS DE LA HISTORIOGRAFÍA LITERARIA ESPAÑOLA (1700-1850)
}

\author{
Jesús Cañas Murillo \\ Universidad de Extremadura \\ jcanas@unex.es
}

\section{LOS OBJETIVOS DE UN ESTUDIO}

$\longrightarrow$

n nuestros días, el papel que ocupa Lope de Vega en la historia de la literatura española está suficientemente clarificado. La crítica y el público admiten, sin discusiones, su contribución esencial en la configuración de la fórmula dramática más importante que existió en la dramaturgia hispana de nuestra Edad Moderna, la predominante en el llamado Siglo de Oro español, la triunfadora entre escritores y público de esa época, la que nos hemos acostumbrado a denominar Comedia Nueva, una manera de hacer teatro a la que el conocido como el Fénix de los Ingenios proporcionó sus ingredientes definitorios, sus constituyentes esenciales, que serían empleados por los escritores que en sus años quisieron continuar su labor renovadora de las formas de componer piezas teatrales (Cañas, 1991; 1995; 1999; 2000; 2003; 2005; 2009a; 2010a).

El problema es conocer si la historiografía literaria ha reconocido, sistemáticamente, esa realidad desde el principio de su historia, que podemos situar, como estudios anteriores han venido demostrando (Cañas, 2019a; 2019; 2019b; 2021; Cañas y Roso, 2019), en los finales del siglo XVII, en el siglo XVIII y en los primeros años del siglo XIX. Ese ha sido el punto de partida de la presente investigación. Nuestro interés ha sido esclarecer tal asunto, indagar sobre las aportaciones legadas a la posteridad sobre estos temas por los primeros estudios que se ocuparon de trabajar en nuestra historia literaria, por los primeros trabajos científicos que vieron la luz sobre historiografía literaria centrada en textos, autores y géneros españoles ${ }^{1}$.

\footnotetext{
1 La visión que de Lope proporciona la primitiva historiografía científica española fue, también, analizada por Ismael López Martín (2019).
} 
Para alcanzar nuestro objetivo hemos seleccionado treinta y seis libros —algunos del mismo autor, o parte de una misma obra o colección — de historiografía literaria cuya elaboración y publicación puede situarse entre los comienzos del reinado del primero de los monarcas Borbones, Felipe V, y mediados del siglo XIX, hacia el año 1850. El corpus que hemos manejado es el siguiente (incluimos las obras por el orden cronológico de su publicación) ${ }^{2}$ :

1. Blas NASARre (1749). «Prologo del que hace imprimir efte Libro» [Dissertacion, o prologo sobre las Comedias de España]. En Comedias, y Entremeses de Miguel de Cervantes Saavedra, el Autor del Don Quixote, divididas en dos Tomos, con una dissertacion, o prologo sobre las Comedias de España. Madrid: Imprenta de Antonio Marin, t. 1, pp. [1]-[52] (edición moderna en Cañas [1992a: 47-101]).

2. Tomás de ERAuso y Zavaleta [Ignacio de Loyola Oyánguren, marqués de la Olmeda] (1750). Discurso crítico sobre el origen, calidad y estado presente de las comedias de España, contra el dictamen que las supone corrompidas, y en favor de sus más famosos escritores, el Dr. Frey Félix Lope de Vega Carpio y D. Pedro Calderón de la Barca, escrito por un Ingenio de esta Corte. Quien le dedica a la M. I. S. la Señora Marquesa de la Torrecilla, \&c. Madrid: Imprenta de Juan de Zúñiga. Con todas las

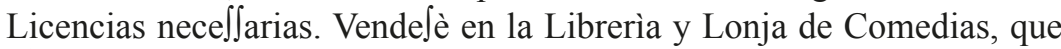
e tà en la Puerta del Sol, à la entrada de la calle de las Carretas.

3. Agustín Montiano y Luyando (1750). Discurso sobre las tragedias españolas. De Don Agustin de Montiano y Luyando, de el Consejo de S. M. su Secretario de la Cámara de Gracia, y Jufficia, y Eltado de Caltilla, Director perpetuo por S. M. de la Real Academia de la Hi toria, y Academico de la Real Academia Elpañola. Con Privilegio. Madrid: Imprenta del Mercurio, por Joseph de Orga, calle de las Infantas (Cañas, 2009b; 2015; 2017).

4. Agustín Montiano y Luyando (1753). Discurso II. sobre las tragedias españolas. De Don Agustin de Montiano y Luyando, del Consejo de S. M. su Secretario de la Camara de Gracia, y Jufficia, y Eltado de Caltilla, Director perpetuo de la Academia de la Hiltoria, y del Numero de la Elpañola, y de la de Buenas Letras de Sevilla, Honorario de la de Barcelona, y de la de las tres Bellas Artes de elta Corte y entre los Arcades de Roma Leghinto Dulichio. Con Licencia. Madrid: Imprenta del Mercurio, por Joseph de Orga, Impre $\iint_{0}$.

\footnotetext{
Todas las citas y referencias extraídas de estos libros que incluyamos en nuestro artículo van referidas a las ediciones aquí detalladas.
} 
5. Juan José López de Sedano (1768). Parnaso Español. Coleccion de Poesías escogidas de los mas célebres Poetas Castellanos. Con Licencia. Madrid: D. Joachin de Ibarra, t. 1. Se hallará este, y los demás que vayan saliendo, en la Librería de Antonio de Sancha, Plazuela de la Paz ${ }^{3}$.

6. Juan José LóPez de Sedano (1770). Parnaso Español. Coleccion de Poesías escogidas de los mas célebres Poetas Castellanos. Con Licencia. Madrid: D. Joachin de Ibarra, Impresor de Cámara de S. M., t. 2. Se hallará en la Librería de Antonio de Sancha, Plazuela del Angel.

7. Juan José López de Sedano (1770). Parnaso Español. Coleccion de Poesías escogidas de los mas célebres Poetas Castellanos. Con Licencia. Madrid: Joachin Ibarra, Impressor de Cámara de S. M., t. 3. Se hallará en la Librería en Antonio de Sancha, Plazuela del Angel.

8. Juan José López de Sedano (1770). Parnaso Español. Coleccion de Poesías escogidas de los mas célebres Poetas Castellanos. Con Licencia. Madrid. Por D. Joachin de Ibarra, Impresor de Cámara de S. M., t. 4. Se hallará en la Librería de Antonio de Sancha, Plazuela del Angel.

9. Juan José López de Sedano (1771). Parnaso Español. Coleccion de Poesías escogidas de los mas célebres Poetas Castellanos. Con Licencia. Madrid: D. Antonio de Sancha, t. 5. Se hallará en su Librería Aduana Vieja.

10. Juan José López de Sedano (1772). Parnaso Español. Coleccion de Poesías escogidas de los mas célebres Poetas Castellanos. Por D. Juan Joseph Lopez de Sedano, Caballero Pensionado de la Real y Distinguida Orden Española de Carlos Tercero, y Académico de la Real Academia de la Historia. Con Licencia. Madrid: D. Antonio de Sancha, t. 6. Se hallará en su libreria, entrada de Barrio-Nuevo.

11. Juan José LóPez de Sedano (1773). Parnaso Español. Coleccion de Poesías escogidas de los mas célebres Poetas Castellanos. Por D. Juan Joseph Lopez de Sedano, Caballero Pensionado de la Real y Distinguida Orden Española de Carlos Tercero, y Académico de la Real Academia de la Historia. Con Licencia. Madrid: D. Antonio de Sancha, t. 7. Se hallará en su libreria, entrada de Barrio-Nuevo.

12. Juan José LóPez de Sedano (1774). Parnaso Español. Coleccion de Poesías escogidas de los mas célebres Poetas Castellanos. Por D. Juan Joseph Lopez de Sedano, Caballero Pensionado de la Real y Distinguida Orden Española de Carlos Tercero, y Académico de la Real Academia de

\footnotetext{
Todas las obras aquí relacionadas de Juan José López de Sedano son tomos de la siguiente colección (1768-1778): Parnaso Español. Coleccion de Poesías escogidas de los mas célebres Poetas Castellanos. Con licencia. Madrid: D. Joachin de Ibarra y por D. Antonio de Sancha, 9 t. (los 1, 2, 3 y 4, publicados por Joachin de Ibarra; los 5, 6, 7, 8 y 9, por Antonio de Sancha).
} 
la Historia. Con Licencia. Madrid: D. Antonio de Sancha, t. 8. Se hallará en su librería en la Aduana Vieja.

13. Juan José LóPez de Sedano (1778). Parnaso Español. Coleccion de Poesías escogidas de los mas célebres Poetas Castellanos. Por D. Juan Joseph Lopez de Sedano, Caballero Pensionado de la Real y Distinguida Orden Española de Carlos Tercero, y Académico de la Real Academia de la Historia. Con Licencia. Madrid: D. Antonio de Sancha, t. 9. Se hallará en su librería en la Aduana Vieja.

14. Xavier LampILlas (1778-1781). Ensayo historico-apologetico de la literatura Española contra las opiniones preocupadas de algunos Escritores modernos Italianos. Disertaciones del Señor Abate Don Xavier Lampillas. Parte Primera de la literatura antigua. Tomo Primero. Traducido

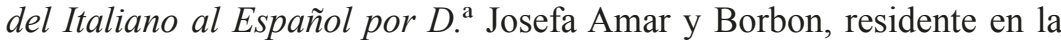
Ciudad de Zaragoza. Con Licencia y Privilegio. Zaragoza: Oficina de Blas Miedes, Impresor de la Real Sociedad ${ }^{4}$.

15. Xavier Lampillas (1783). Ensayo historico-apologetico de la literatura Española contra las opiniones preocupadas de algunos Escritores modernos Italianos. Disertaciones del Señor Abate Don Xavier Lampillas. Parte Primera de la literatura antigua. Tomo Segundo. Traducido del Italiano al Español por D. ${ }^{a}$ Josefa Amar y Borbon, residente en la Ciudad de Zaragoza, Socia de merito de la Real Sociedad Económica Aragonesa de Amigos del País. Con Licencia y Privilegio. Zaragoza: Oficina de Blas Miedes, Impresor de la Real Sociedad.

16. Xavier Lampillas (1783). Ensayo historico-apologetico de la literatura Española contra las opiniones preocupadas de algunos Escritores modernos Italianos. Disertaciones del Señor Abate Don Xavier Lampillas. Parte Segunda de la literatura moderna. Tomo Tercero. Traducido del Italiano al Español por D. ${ }^{a}$ Josefa Amar y Borbon, residente en la Ciudad de Zaragoza, Socia de merito de la Real Sociedad Económica Aragonesa de Amigos del País. Con Licencia y Privilegio. Zaragoza: Oficina de Blas Miedes, Impresor de la Real Sociedad.

17. Xavier Lampillas (1784). Ensayo historico-apologetico de la literatura Española contra las opiniones preocupadas de algunos Escritores modernos Italianos. Disertaciones del Señor Abate Don Xavier Lampillas. Parte Segunda de la literatura moderna. Tomo Quarto. Traducido del

\footnotetext{
Todos los tomos de Xavier Lampillas que aquí recogemos, forman parte de una traducción de época de una obra inicialmente escrita en italiano: (1778-1781). Saggio Storico-Apologetico della Letteratura Spagnuola Contro le Pregiudicate Opinioni di Alcuni Moderni Scrittori Italiani. Dissertazioni del Signor Abate D. Saverio Lampillas. Genova: Presso Felice Repetto in Canneto, Con licenza de' Superiori, 6 t.
} 
Italiano al Español por D. ${ }^{a}$ Josefa Amar y Borbon, residente en la Ciudad de Zaragoza, Socia de merito de la Real Sociedad Económica Aragonesa de Amigos del País. Con Licencia y Privilegio. Zaragoza: Oficina de Blas Miedes, Impresor de la Real Sociedad.

18. Xavier Lampillas (1784). Ensayo historico-apologetico de la literatura Española contra las opiniones preocupadas de algunos Escritores modernos Italianos. Disertaciones del Señor Abate Don Xavier Lampillas. Literatura moderna. Tomo Quinto. Traducido del Italiano al Español por D. ${ }^{a}$ Josefa Amar y Borbon, residente en la Ciudad de Zaragoza, Socia de merito de la Real Sociedad Económica Aragonesa de Amigos del País. Con Licencia y Privilegio. Zaragoza: Oficina de Blas Miedes, Impresor de la Real Sociedad.

19. Xavier Lampillas (1789). Ensayo historico-apologetico de la literatura Española contra las opiniones preocupadas de algunos Escritores modernos Italianos. Disertaciones del Señor Abate Don Xavier Lampillas. Literatura moderna. Tomo Sexto. Traducido del Italiano al Español por $D^{a}$. Josefa Amar, y Borbon, Socia de mérito de la Real Sociedad Aragonesa, y de honor y mérito de la Junta de Señoras, agregada á la Real Sociedad de Madrid. Segunda edicion: corregida, enmendada, é ilustrada con notas, por la misma Traductora. Con Licencia. Madrid: Imprenta de Don Pedro Marin.

20. Xavier Lampillas (1789). Respuesta del Señor Abate Don Xavier Lampillas a los cargos recopilados por el Señor Abate Tiraboschi en su Carta al Señor Abate N. N. sobre el Ensayo Historico-Apologetico de la Literatura Española Traducida del Italiano por D. ${ }^{a}$ Josefa Amar y Borbon. Va añadido un Indice Alfabético de los principales autores, y matérias que comprenden los seis tomos de la obra del Abate Lampillas, formado por la Traductora. Con Licencia. Madrid: Imprenta de Don Pedro Marin, Impresor de la Real Sociedad, t. $7^{5}$.

\footnotetext{
Esta obra fue publicada por Lampillas, primero, en italiano como respuesta a los ataques recibidos por su Saggio Storico-Apologetico della Letteratura Spagnuola, citado: Risposta del Sig. Abate D. Saverio Llampillas alle accuse compilate dal Sig. Abate Girolamo Tiraboschi nella sua lettera al Sig. abate N. N. intorno al Saggio Storico-Apologetico della Letteratura Spagnuola (Genova, 1778), y Risposta dell'Abate Saverio Llampillas alla lettera scrittagli dell'abate Saverio Bettinelli sopra il tomo I della parte II del Saggio Storico-Apologetico della Letteratura Spagnuola e pubblicata nel tomo XX del Nuovo Giornale di Modena (1780). En la primera edición española (1786): Respuesta del Señor Abate Don Xavier Lampillas a los cargos recopilados por el Señor Abate Tiraboschi en su Carta al Señor Abate N. N. sobre el Ensayo Historico-Apologetico de la Literatura Española Traducida del Italiano por Da Josefa Amar y Borbon. Vá añadido un Indice Alfabético de los principales Autores, y Matérias que comprenden los seis tómos de la Obra del Abate Lampillas, formado por la Traductora. Con Licencia y Privilegio. Zaragoza: Oficina de Blas Miedes, impresor de la Real Sociedad.
} 
21. Juan ANDRÉs (1787). Origen, progresos y estado actual de toda la Literatura. Obra escrita en italiano por el Abate D. Juan de Andrés, individuo de las Reales Academias Florentina, y de las Ciencias y buenas Letras de Mantua: y traducida al castellano por D. Carlos Andres, individuo de las Reales Academias Florentina, y del Derecho Español y Público Matritense. Madrid: Don Antonio de Sancha, t. 4. Se hallará en su librería en la Aduana Vieja. Con las Licencias necesarias ${ }^{6}$.

22. Vicente García de la Huerta (1785). «Prólogo del Colector». En Vicente García de la Huerta, Theatro Hespanol. Por Don Vicente García de la Huerta. Parte primera. Comedias de figurón. Con licencia. Madrid: Imprenta Real, t.1, pp. I-CCVI (edición moderna en Cañas [2013: 169-300]).

23. Manuel García de Villanueva Parra Hugalde (1788). Manifiesto por los Teatros españoles, y sus Actores, que dictó la imparcialidad; y se presenta al publico, a fin de que lo juzgue el prudente. Compuesto por Manuel Garcia de Villanueva, Parra, Hugalde, Moya, y Madrid, \&c. Primer Galan en la Compañía de Eusebio Ribera. Madrid: Imprenta de la Viuda de Ibarra. Con licencia (Cañas, 1992b).

24. Joseph Antonio Álvarez y Baena (1789). Hijos de Madrid, Ilustres en Santidad, Dignidades, Armas, Ciencias y Artes. Diccionario histórico por el orden alfabético de sus nombres, que consagra al Ilmo. y Nobilísimo Ayuntamiento de la Imperial y Coronada Villa de Madrid, su autor D. Joseph Antonio Álvarez y Baena, vecino y natural de la misma Villa. A. B. C. D. E. Madrid: Oficina de Don Benito Cano, t. 1.

25. Joseph Antonio Álvarez y Baena (1790). Hijos de Madrid, Ilustres en Santidad, Dignidades, Armas, Ciencias y Artes. Diccionario histórico por el orden alfabético de sus nombres, que consagra al Ilmo. y Nobilísimo Ayuntamiento de la Imperial y Coronada Villa de Madrid, su autor D. Joseph Antonio Álvarez y Baena, vecino y natural de la misma Villa. F. G. H. I. Madrid: Oficina de Don Benito Cano, t. 2.

\footnotetext{
Se trata de una traducción de época de una obra inicialmente escrita en italiano: Juan Andrés (1782-1799). Dell'origine, progressi e stato attuale d'ogni letteratura. Parma: Stamperia Reale, 7 t. +1 de Addenda (Parma, Tipografía Ducale Bodoni, 1822); edición revisada y ampliada por el autor (1808-1817): Dell'origine, progressi e stato attuale di ogni letteratura. Roma, 8 tomos en 9 vols. (Origen, progresos y estado actual de toda la literatura. Carlos Andrés [trad.]. Madrid: Antonio de Sancha, 1784-1806). Hay edición moderna de la misma: Juan Andrés, Origen, progresos y estado actual de toda la literatura. Carlos Andrés (trad.) (vols. I-V) y Santiago Navarro Pastor (trad.) (vol. VI), Pedro Aullón de Haro (dir.), J. García Gabaldón, S. Navarro Pastor y C. Valcárcel (eds.) I: Estudio Preliminar, Historia de toda la Literatura, II: Poesía, III: Elocuencia, Historia, Gramática, IV: Ciencias Naturales, V: Ciencias Naturales, VI: Ciencias Eclesiásticas, Addenda, Onomástica. Madrid: Verbum / Biblioteca Valenciana, 1997-2002, 6 t.
} 
26. Joseph Antonio Álvarez y Baena (1790). Hijos de Madrid, Ilustres en Santidad, Dignidades, Armas, Ciencias y Artes. Diccionario histórico por el orden alfabético de sus nombres, que consagra al Ilmo. y Nobilísimo Ayuntamiento de la Imperial y Coronada Villa de Madrid, su autor D. Joseph Antonio Álvarez y Baena, vecino y natural de la misma Villa. J. L. Madrid: Oficina de Don Benito Cano, t. 3.

27. Joseph Antonio Álvarez y Baena (1791). Hijos de Madrid, Ilustres en Santidad, Dignidades, Armas, Ciencias y Artes. Diccionario histórico por el orden alfabético de sus nombres, que consagra al Ilmo. y Nobilísimo Ayuntamiento de la Imperial y Coronada Villa de Madrid. Su Autor D. Joseph Antonio Álvarez y Baena, vecino y natural de la misma Villa. M. N. P. R. S. T. U. V. Z. Con aumentos é Índices. Madrid: Oficina de Don Benito Cano, t. 4.

28. Manuel García de Villanueva Parra Hugalde (1802). Origen, épocas y progresos del teatro español: discurso histórico, al que acompaña un resumen de los Espectáculos, Fiestas y Recreaciones que desde la mas remota antigüedad se usaron entre las naciones mas célebres: $y$ un compendio de la historia general de los teatros hasta la era presente. Por Manuel García de Villanueva Hugalde y Parra, primer actor de una de las compañias cómicas de esta Corte. Con privilegio real. Madrid: Imprenta de Don Gabriel de Sancha. Se hallará en las Librerías de Sancha Calle del Lobo y del Principe, de Quiroga calle de las Carretas y de Castillo frente a Sn. Felipe el Real (Cañas, 2010b).

29. Casiano Pellicer (1804). Tratado historico sobre el origen y progresos de la Comedia y del Histrionismo en España: ó Noticia de algunos célebres Comediantes y Comediantas, asi antiguos como modernos. Por D. Casiano Pellicer, Oficial de la Real Biblioteca de S. M. Parte Segunda. Madrid: Imprenta de la Administracion del Real Arbitrio de Beneficencia, $2 \mathrm{t}$.

30. Fiedrich Bouterwek (1824 [1804]). Historia de la Literatura Española. Traducida y adicionada por José Gómez de la Cortina y Nicolás Hugalde y Mollinedo. Madrid: Imprenta de D. Eusebio Aguado, impresor de la Real Casa ${ }^{7}$.

31. Jean Charles Léonard Simonde De Sismondi (1841 [1813]). Historia de la literatura española desde mediados del siglo XII hasta nuestros días.

Esta obra se publicó por primera vez en alemán: Fiedrich Bouterwek (1804). Geschichte der spanischen Poesie und Beredsamkeit. Göttingen, t. 3 de su (1801-1819). Geschichte der Poesie und Beredsamkeit seit dem Ende des Dreizehnten Jahrhunderts. Göttingen, 12 t. Manejamos la versión española que citamos aquí, de la cual hay edición moderna de 2002, realizada por Carmen Valcárcel Rivera y Santiago Navarro Pastor y publicada en la editorial madrileña Verbum. 
Dividida en lecciones, escrita en francés por Mr. Sismonde de Sismondi; traducida y completada por D. José Lorenzo Figueroa. Sevilla: Imprenta de Álvarez y Compañía, calle Rosillas, n. $^{\circ} 27$, t. $^{8}$.

32. Jean Charles Léonard Simonde De Sismondi (1842 [1813]). Historia de la literatura española desde mediados del siglo XII hasta nuestros días. Principiada á traducir, anotar y completar por D. José Lorenzo Figueroa y proseguida por D. José Amador de los Rios, socio de número de la Academia Sevillana de Buenas Letras, y de mérito, y corresponsal de otras corporaciones literarias del reino. Sevilla: Imprenta de Álvarez y Compañía, calle de Rosillas, n. ${ }^{\circ} 27$, t. 2.

33. Leandro FERnándeZ de Moratín (1838 [1830]). Orígenes del teatro español, seguidos de una coleccion escogida de piezas dramáticas anteriores á Lope de Vega, por Don L. F. de Moratin, con un apéndice Por Don E. de Ochoa. París: Librería Europea de Baudry, Calle du Coq-Saint-Honoré, 9, cerca del Louvre?.

34. Antonio Gil de ZÁrate (1844). Manual de Literatura, por D. Antonio Gil de Zárate. Segunda Parte. Resumen Historico de la Literatura Española. Madrid: Boix, Editor, Imprenta y Libreria, Calle de Carretas, n. ${ }^{\circ} 8$, t. 2.

35. Adolfo Federico, CONDE DE SсHACK (1885-1887 [1845]). Historia de la literatura y del arte dramático en España. Traducida directamente del alemán al castellano por Eduardo de Mier. Madrid: Imprenta y Fundición de M. Tello, impresor de Cámara de S. M., Isabel la Católica, $23,5 \mathrm{t}^{10}$

36. George TiCKNOR (1851-1856 [1849]). Historia de la Literatura Española. Traducida al castellano, con adiciones y notas críticas, por D. Pascual de Gayangos y D. Enrique de Vedia. Madrid: Imprenta y Estereotipia de M. Rivadeneyra, 4 t. ${ }^{11}$

8 La versión original se publicó en francés: Jean Charles Léonard Sismonde de Sismondi (1813). Histoire de la Littérature Espagnole, incluida en su obra De la Littérature du Midi de l'Europe. París: [Crapelet], t. 3 y 4 . Citamos por la edición española aquí recogida.

9 Citamos por esta edición, aunque la obra fue publicada antes: Leandro Fernández de Moratín (1830). «Orígenes del teatro español». Obras de D. Leandro Fernandez de Moratin, dadas á luz por la Real Academia de la Historia. Madrid: Aguado, impresor de Cámara de S. M. y de su Real Casa, t. 1.

10 Esta edición es la versión española del siguiente trabajo: Adolf Fiedrich Schack (1845). Geschichte der dramatischen Literatur und Kunst in Spanien. Berlin: Dunder und Hamblot, 3 t.

11 Todas las citas que incluyamos en nuestro artículo de esta obra, van referidas a esta edición, aunque se trata de la versión española del siguiente trabajo: George Ticknor (1849). History of the Spanish Literature. London: John Murray [William Clowes and Sons], 3 t. 


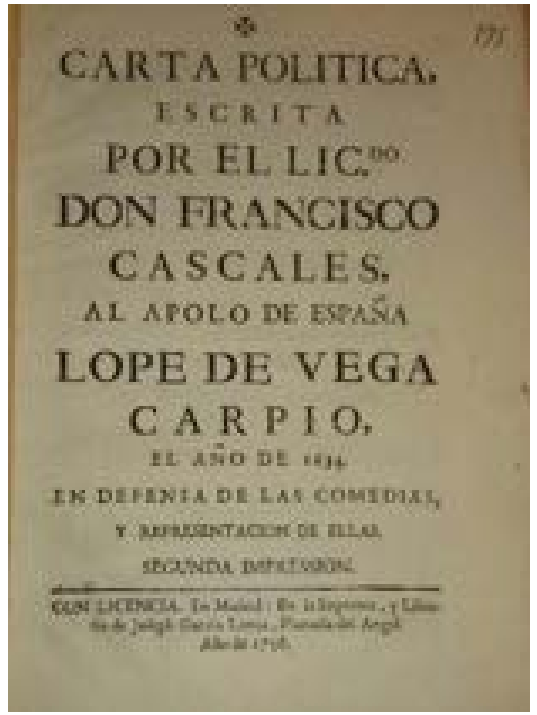

[IMAGEN 1]. Francisco Cascales (1756). Elogio a Lope de Vega. Madrid: Imprenta de Joseph García Lanza.

\section{LA PRIMERA HISTORIOGRAFÍA LITERARIA CIENTÍFICA ESPAÑOLA ANTE LOPE}

El puesto ocupado por Lope de Vega en la historia de la dramaturgia española es sistemáticamente abordado en las obras que han servido de base para nuestra investigación. Todos los autores consultados, sin excepción, incluyen en la exposición de sus indagaciones el nombre del Fénix de los Ingenios, en mayor o menor medida. Todos intentan destacar la importancia que realmente se le ha otorgado en la trayectoria histórica del teatro español, del Siglo de Oro, evidentemente, pero también de épocas posteriores.

En el tratamiento de la figura y la producción de Lope de Vega, y en la valoración de su importancia histórica, que hallamos en las fuentes utilizadas, detectamos una serie amplia de concomitancias entre unas y otras. Para tratar sobre el Fénix prácticamente todos toman como referente básico dos fuentes documentales escritas en el siglo XVII: el «Prólogo al lector» de Miguel de Cervantes, incluido en la primera edición de sus Ocho comedias y ocho entremeses nuevos, nunca representados, obra impresa «En Madrid, Por la Viuda de Alonfo Martin, Año 1615»; y en «Fama Posthuma, a la vida y muerte del Doctor Frey Lope Felix de Vega Carpio. Escrita por el Doctor Ivan Perez de Montaluan, Natural de Madrid, y Notario del Santo Oficio», incluida en el libro, recopilado por el mismo Juan Pérez de Montalbán, Fama posthvma a la vida y muerte del Doctor Frey Lope 
Felix de Vega Carpio. Y Elogios Panegiricos a la Inmortalidad de sv nombre. Escritos por los mas esclarecidos ingenios, publicado en «Madrid, en la Imprenta del Reyno, Año 1636».

Del mismo modo todas, en este caso, toman a Lope de Vega como referente ineludible y representante importante de su época y del teatro español del Siglo de Oro. Es habitual encontrar en las obras consultadas expresiones del tipo «el tiempo de Lope de Vega» (Gil de Zárate, 1844: 88; conde de Schack, 1845: I, 433; conde de Schack, 1845: II, 222; Ticknor, 1851-1856: III, 18); «no imitando en esto á Lope de Vega» (Gil de Zárate, 1844: 305), «era amigo de Lope de Vega» (Gil de Zárate, 1844: 305), «seis años despues de Lope de Vega» (Gil de Zárate, 1844: 486); piezas dramáticas anteriores á Lope de Vega (Leandro Fernández de Moratín, 1830), «hasta que Lope de Vega» (Leandro Fernández de Moratín, 1830: 10), «anteriores al tiempo en que Lope de Vega comenzó á escribir» (Leandro Fernández de Moratín, 1830: 10); un «antes y después de Lope de Vega» (conde de Schack, 1845: I, 262, n. 1); «imitaciones serias del estilo de Lope de Vega» (conde de Schack, 1845: II, 60); «comparten con Lope de Vega» (conde de Schack, 1845: I, 458); «ingenios que, como Lope de Vega» (Gil de Zárate, 1844: 329); «del estilo de Lope de Vega» (conde de Schack, 1845: II, 60, «hacia fines de la época en que vivió Lope de Vega» (conde de Schack, 1845: V, 193); «después de las de Lope de Vega» (conde de Schack, 1845: V, 236); «respecto á las de Lope de Vega» (conde de Schack, 1845: V, 346); «despues de Lope de Vega» (Ticknor, 18511856: I, 317); «en tiempo de Cervantes y de Lope de Vega» (Ticknor, 1851-1856: I, 357); «período desde Lope de Rueda hasta Lope de Vega» (Ticknor, 1851-1856: II, 162); «del tipo que triunfantemente habían establecido Lope de Vega y sus imitadores» (Ticknor, 1851-1856: II, 226); «se encuentra ya en Lope de Vega» (Ticknor, 1851-1856: III, 81); «imitadas á las de Lope de Vega» (Ticknor, 1851-1856: III, 108), etc. Los ejemplos podrían multiplicarse constantemente.

Lope es citado en, prácticamente, todos los trabajos manejados como autoridad. Su Arte Nuevo es presentado como uno de los primeros tratados de Poética y a él se acude para explicar caracteres de su teatro, o del compuesto por sus seguidores ( «legun lo confie $\iint_{a}$ en $\int \mathrm{u}$ Arte de Comedias» [Montiano, Discurso I: 68]; «El primero [en escribir una Poética] fue Lope de Vega en su Arte nuevo» [Lampillas, 1783: III, 132]; García de la Huerta, 1785: XVII-XVIII; García de Villanueva, 1802: 275-285; «su agradable poemita didáctico intitulado Arte nuevo de hacer comedias» [Ticknor, 1851-1856: II, 307]; Simonde de Sismondi, 1813: I, 295; Gil de Zárate, 1844: I, 235; Ticknor, 1851-1856: II, 316). Su Laurel de Apolo se convierte en la fuente a la que se acude para conocer la valoración que el Fénix realiza de muchos de los autores que se citan (López de Sedano, 1770: 2, V, XI, XV, XXV, XXIX; López de Sedano, 1770: 4, xxiii, xlv, xlvi; López de Sedano, 1771: 5, xxviii, xxxii, liii; López de Sedano, 1774: 8, xix, xxxv; López 
de Sedano, 1778: 9, xvi, xxxviii, Índice: xxix; Álvarez y Baena, 1789: I, 7, 44, 46, 56, 71, 88, 99, 137, 140, 146, 312, 316, 318, 357, 401; Álvarez y Baena, 1790: II, 15, 42, 43, 78, 122, 127, 133, 158, 163, 187, 203, 266, 271, 321, 326, 330, 404; Álvarez y Baena, 1790: III, 19, 31, 160, 161, 165, 167, 169, 170, 189, 218, 223, 340; Álvarez y Baena; 1791, IV, 33, 49, 86, 109, 132, 192, 199, 201, 205, 210, 291, 292, 320, 337, 406, 411, 414; Simonde de Sismondi, 1813: I, 371; conde de Schack, 1845: IV, 10, 192: Ticknor, 1851-1856: III, 507), o a la que se acude para corroborar que un autor no es mencionado por el Fénix en esa obra (López de Sedano, 1770: IV, xlvii). Su forma de hacer teatro es empleada como medio de definir la dramaturgia de muchos comediógrafos que se destacan o recuerdan («Siguiole, con otros, Don Pedro Calderòn de la Barca» [Erauso y Zavaleta, 1750: (14)]; Lampillas, 1784: IV, 162-176; García de Villanueva, 1802: 273; Casiano Pellicer, 1804: I, 232-234; Gil de Zárate, 1844: 181, 230, 273, 274, 380, 390, 392; conde de Schack, 1845: II, 80, 158, 274; conde de Schack, 1845: IV, 447; Ticknor, 1851-1856: II, 211, 226, 424; Ticknor, 1851-1856: III, 82, 108, 495; Ticknor, 1851-1856: IV, 31); o de ensalzar a escritores que gozaron de su amistad, o de relaciones de parentesco con él, o sobre cuyas obras Lope escribió aprobaciones, poemas laudatorios u otros textos (López de Sedano, 1770: IV, xlvi, xlvii; López de Sedano, 1778: IX, 360-368; Casiano Pellicer, 1804: II, 202; Ticknor, 1849: III, $82,216,514,515,524,556)$.

Coincidencia entre los primeros historiadores científicos de la literatura es también destacar la gran importancia que tuvo Lope de Vega entre los escritores de su tiempo, y aun entre los posteriores a él, y situarlo como cabeza de los dramaturgos barrocos, o, al menos, como un autor importante y respetado, pese a que lo puedan atacar por su concepción del teatro. Sin ánimos de exhaustividad, lo resaltan como escritor de mención necesaria y, por ello, lo mencionan Blas Nasarre (1749), Agustín Montiano y Luyando (1750; 1753), Tomás de Erauso y Zavaleta $(1750)^{12}$, Juan José López de Sedano $(1770)^{13}$, Xavier Lampillas $(1783)^{14}$, Juan Andrés (1784-1806) ${ }^{15}$, Vicente García de la Huerta (1785),

12 «todos los Poetas, que de mucho tiempo à efta parte, mantienen, è ilu ftran el Theatro Elpañol, han imitado à Lope, ob $\int$ ervando $\int u$ methodo con mas, ò menos fuerza. Sus mi $\int$ mos contemporàneos emulantes, de fpreciaron las reglas, tomando, en mucha parte, Jus lecciones» (1750: 171).

13 «LOPE fue verdadero monstruo de la naturaleza. No se cuenta de Poeta alguno entre los antiguos y modernos que haya escrito tanto, porque no se cuenta de otro que haya tenido igual fertilidad ni abundancia de talento» (1770: III, x).

14 «Italianos, que hablando de Poetas Españoles no saben nombrar sino á Lope de Vega, que aunque tiene mas mérito del que piensan, no obstante no se halla alistado entre los Poetas del siglo de oro de la poesía Española» (1783: II, 260).

15 «Con mas fundamento pretenden algunos que Dryden deba llamarse el Lope de Vega de los ingleses: la facilidad de su vena poetica le daba algun derecho para entrar en parangon con la maravillosa fluidez de Lope de Vega: pero de la admirable fecundidad de fantasía del comico español, ¿qué rastro puede descubrirse en Dryden, cuyas piezas dramáticas manifiestan casi por 
Manuel García de Villanueva (1802) ${ }^{16}$, Joseph Antonio Álvarez y Baena (17891791), Casiano Pellicer (1804) ${ }^{17}$, Fiedrich Bouterwek $(1804)^{18}$, Jean Charles Léonard Simonde de Sismondi $(1813)^{19}$, Antonio Gil de Zárate $(1844)^{20}$, Leandro Fernández de Moratín (1830) ${ }^{21}$, Adolfo Federico, conde de Schack (1845) 22 $^{2}$ y George Ticknor (1851-1856) ${ }^{23}$.

En el espacio que dedican los autores consultados a Lope de Vega en las páginas de sus escritos hay notables diferencias entre ellos. Podemos establecer, tomando como base ese criterio, varios grupos. El primero de ellos estaría integrado por las obras que le dedican un menor número de líneas. Serían la Dissertacion, o prologo sobre las Comedias de España de Blas Nasarre; los dos trabajos de Agustín Montiano y Luyando (Discurso sobre las tragedias

todas partes su esterilidad, que necesitaba ir en busca de los persamientos de Shakespear y de otros Ingleses; y de mendigar de los Españoles los enredos; de muchas fabulas?» (1784-1806: IV, 235-236).

16 «Para dar una completa idea de la gloria que le compete, pues fue Lope el que (digámoslo así) abrió el primer camino á el orden y cultura de las composiciones teatrales españolas, segun el gusto reynante de su siglo; me parece conveniente hacer relacion de sus conocimientos y progresos en el discurso de su vida» (1802: 273).

17 «Lope de Vega bastaba para proveer á todos los Teatros de España; y no solo los preveia, sino que los autores de Comedias solo parece estimaban las de Lope» (1804: I, 156).

18 «Mas si no pareciesen de bastante peso las autoridades alegadas en prueba de nuestras aserciones, oigamos á Lope de Vega, que aunque no compuso ningun Arte de hablar en prosa y verso, era muy capaz de haberlo hecho sin necesidad de andar mendigando auxilios agenos» (1804: 172).

19 «No solamente debemos considerar por sí mismo al gran poeta, á quien dió España el nombre desde el año de 1562 hasta el de 1635 de Fenix de los ingenios: Lope de Vega merece tambien llamar nuestra atencion por haber reunido y reflejado en sus obras el espíritu de su siglo» (1813: II, 49).

20 «A no existir Lope de Vega, Tirso de Molina hubiera sido el rey de la escena española» (1844: II, 274).

21 El libro ofrece, escribe Leandro Fernández de Moratín en el prólogo, «á los inteligentes un resúmen crítico en que manifiesto cual fué el origen de nuestra escena, cuales sus progresos, y cuales las causas que influyeron en las alteraciones que padeció, hasta que Lope de Vega las autorizó con su ejemplo» (1830: 10); y, después, sobre el papel de Lope en la historia del teatro español, explica: «En ellos [los teatros madrileños de la Cruz y del Príncipe] empezaron á oirse con admiracion los fáciles versos del jóven Lope de Vega, aquel hombre estraordinario á quien la naturaleza dotó de imaginacion tan fecunda, de tan afluente vena poética, que en ninguna otra edad le ha producido semejante» (1830: 53).

22 «Cervantes, Calderón y Lope de Vega, viven y vivirán siempre mientras la cultura y la admiración á las grandes creaciones del espíritu duren entre los hombres» (1845: I, 47-48). Y, más adelante, podemos leer: «ningún poeta de la antigüedad ni de los siglos más modernos puede compararse á Lope de Vega, porque á él debe su existencia la comedia española, la cual, descartando de ella algunos defectos insignificantes, es, sin disputa, por su gran belleza, la primera del mundo» (1845: V, 200).

23 «Lope entendía perfectamente el arte de captarse el favor y voluntad del público, y que supo fundar y levantar el edificio de su fama como primer poeta dramático de su tiempo» (1851-1856: II, 392). 
españolas, y Discurso II. sobre las tragedias españolas); el Ensayo historico-apologetico de la literatura Española contra las opiniones preocupadas de algunos Escritores modernos Italianos. Disertaciones del Señor Abate Don Xavier Lampillas, el Origen, progresos y estado actual de toda la Literatura. Obra escrita en italiano por el Abate D. Juan de Andrés, individuo de las Reales Academias Florentina, y de las Ciencias y buenas Letras de Mantua; el prólogo del Theatro Hespañol de Vicente García de la Huerta; el Manifiesto por los Teatros españoles, y sus Actores, que dictó la imparcialidad; y se presenta al publico, a fin de que lo juzgue el prudente. Compuesto por Manuel Garcia de Villanueva, Parra, Hugalde, Moya, y Madrid, \&c. Primer Galan en la Compañia de Eusebio Ribera; y la Historia de la Literatura Española de Fiedrich Bouterwek.

El segundo grupo estaría integrado por los autores que más espacio y atención dedican a la figura y a la obra de Lope de Vega: Tomás de Erauso y Zavaleta, con su Discurso crítico sobre el origen, calidad y estado presente de las comedias de España, contra el dictamen que las suponen corrompidas, y en favor de sus más famosos escritores, el Dr. Frey Félix Lope de Vega Carpio y D. Pedro Calderón de la Barca, escrito por un Ingenio de esta Corte; Juan José López de Sedano, con su Parnaso Español. Coleccion de Poesías escogidas de los mas célebres Poetas Castellanos (especialmente su t. 3); Joseph Antonio Álvarez y Baena, con sus Hijos de Madrid, Ilustres en Santidad, Dignidades, Armas, Ciencias y Arte (especialmente su t. 2); Casiano Pellicer, con su Tratado historico sobre el origen y progresos de la Comedia y del Histrionismo en España: ó Noticia de algunos célebres Comediantes y Comediantas, asi antiguos como modernos (especialmente su t. 1); Jean Charles Léonard Simonde de Sismondi, con su Historia de la literatura española desde mediados del siglo XII hasta nuestros días; Antonio Gil de Zárate, con su Manual de Literatura (especialmente su t. 2); Adolfo Federico, conde de Schack, Historia de la literatura y del arte dramático en España (especialmente su t. 2); y George Ticknor, Historia de la Literatura Española (especialmente su t. 2).

El tercer grupo recogería los trabajos que reflejan una situación intermedia entre los otros dos, los trabajos que se ocupan de Lope de Vega con cierta moderación. Se incluirían: el Origen, épocas y progresos del teatro español: discurso histórico, al que acompaña un resumen de los Espectáculos, Fiestas y Recreaciones que desde la mas remota antigüedad se usaron entre las naciones mas célebres: y un compendio de la historia general de los teatros hasta la era presente de Manuel García de Villanueva; y Orígenes del teatro español, seguidos de una coleccion escogida de piezas dramáticas anteriores á Lope de Vega de Leandro Fernández de Moratín. 
En la valoración concreta de la figura y de las creaciones de Lope de Vega que se recoge en las fuentes que hemos utilizado, también hallamos diferencias entre unos estudios y otros. En general, los más antiguos en elaboración reflejan una postura más condicionada por los gustos teatrales propios del siglo XVIII, de los años en los que vivieron sus autores. Los más recientes, los más próximos a nuestros días en ver la luz, suelen tratar, en general, de ser más ecuánimes, $\mathrm{y}$, sin eludir presentar críticas negativas sobre algunas facetas de los escritos del Fénix, intentan destacar, con mayor o menor incidencia, los aspectos positivos de su producción.

Las peores valoraciones las hallamos en la Dissertacion de Blas Nasarre, en la cual podemos leer juicios como los siguientes: «Su Arte es la mas evidente prueba de Ju deforden: es verdad, que quilo en èl hacer la apologia, y defen $\int a$ de $\int u s$ Comedias, fundandolo todo en el mal gufto de los oyentes, y de los Reprefentantes» (1749: 23); «Nada perderia Elpaña en que llamal Jen ignorante Italia, y Francia al

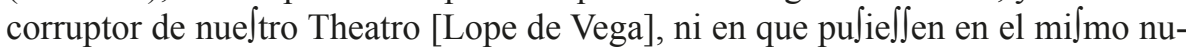
mero à los que lo imitaron, y en efpecial al que llaman Jin titulo alguno Principe de los Poetas Cómicos» (1749: 24); «Del primer corrompedor del Theatro no hay que hablar, y balta creer lo que èl milmo dice de sì» (1749: 25); «Tenemos ciertamente muchas piezas de Theatro ef critas con todo el arte: [...] pero no hay que bufcar e ftas Comedias entre las de Lope de Vega, ni las de Don Pedro Calderon, ni de otros, que los imitaron» (1749: 28).

En los dos Discursos de Agustín Montiano y Luyando, la valoración de Lope es más equilibrada. Se destacan defectos, pero se reconocen logros y puntos positivos. Así, «Entran [en las tragedias escritas con arreglo al arte] de de aqui Jeis Tragedias del celebrado Fr. Lope Félix de Vega-Carpio, que Jon las que he hallado en veinte y cinco libros de Comedias Juyas» (1750: 48); «los ver Jos de Lope llevan configo generalmente la executoria del buen lenguage, y de los mejores conceptos» (1750: 50); «Lope, como parcial de la alteración del Theatro, Jegun lo confie $\iint \mathrm{a}$ en $\int \mathrm{u}$ Arte de Comedias, elogia à Virues por Autor de las mejores reglas Comicas» (1750: 68); «[Los autores] olvidaron, cali en un todo, las reglas antiguas; y entregados Jin re erva, à las que autorizaba la moda, y el credito de Lope de Vega, à de jpique de la razon; Jucedieron las nuevas compoficiones» (1750: 69); «Entre los que ocupan el mas diftinguido lugar, conjiguiò Lope de Vega hacer famo $\int_{a}$ la confe $\int$ sion de $\int_{u}$ error, que es buen teftimonio de $\int_{u}$ elevado merito, ganar reputacion con lo propio que tantos la han perdido» (1753: 12-13).

A principios del siglo XIX, Jean Charles Léonard Simonde de Sismondi ya muestra una postura más templada en la consideración de los textos de Lope y en la evaluación de sus aportaciones. Escribe juicios negativos: «La inconcebible fertilidad de Lope había sostenido su teatro, á pesar del poco cuidado y del poco tiempo, que empleaba en la correccion de sus dramas: pero sus demas poesías, 
producidas por un trabajo tan precipitado, son únicamente rudos, que casi nadie tiene valor para leer» (1813: 76). Pero también puede afirmar que «Cualquiera que sea sin embargo, la rudeza y grosería de la mayor parte de los dramas de Lope de Vega, no puede decirse que sea su lectura enfadosa, ni que decaiga un punto el interes de la accion, causandonos la impaciencia y languidez, que las tragedias malas ó medianas de los poetas franceses de segundo órden nos inspiran» (1813: II, 49). Por el contrario, los continuadores de Simonde de Sismondi, José Lorenzo Figueroa y José Amador de los Rios, en la versión española de su Historia de la literatura española, que es la que manejamos, discrepan, abiertamente, del suizo y de parte de sus ataques contra el Fénix: «Injusta es, sobre ser en estremo inesacta, la calificacion que hace Mr. Sismonde de Sismondí de las Obras sueltas de Lope de Vega. No solamente se hallan entre estas trozos de admirable y castiza poesia castellana, sino tambien escelentes composiciones, que pueden presentarse como modelos en su género» (1813: II, 385).

A diferencia de los autores que acabamos de mencionar, encontramos uno de los consultados que hace una defensa a ultranza de Lope de Vega, junto a su más joven seguidor Pedro Calderón de la Barca. Se trata de Ignacio de Loyola y Oyanguren, marqués de la Olmeda, que firma con varios pseudónimos, el más conocido de los cuales es Tomás de Erauso y Zabaleta. Sus elogios los incluye en su obra, no firmada, Discurso crítico sobre el origen, calidad y estado presente de las comedias de España, contra el dictamen que las suponen corrompidas, y en favor de sus más famosos escritores, el Dr. Frey Félix Lope de Vega Carpio y D. Pedro Calderón de la Barca, escrito por un Ingenio de esta Corte, aparecida en «Madrid, En la Imprenta de Juan de Zúñiga, Año MDCCL» (1750). Aquí podemos encontrar afirmaciones del tipo siguiente: «Son las Comedias de Epaña, y en e fpecial las de los venerados Lope de Vega, Calderon, y Jus Imitadores, el mas dulce agregado de la Jabidurìa, de la discrecion, de la en $\int$ eñanza, del exemplo, del chilte, y de la gracia» (1750: [9]); «En las Comedias E Ejpañolas, que Jon de aquella Jublimada esfera, à que las

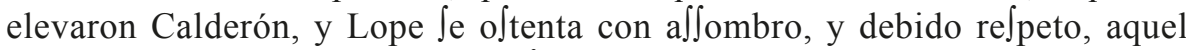
bello caràcter, que à las Damas diftingue en fueros, en gracia, y en dominio» (1750: [10]); «Fuè Lope de Vega el primero, que en Elpaña pufo las Comedias en methodo, a asignando reglas, y preceptos, para que el Theatro, con util

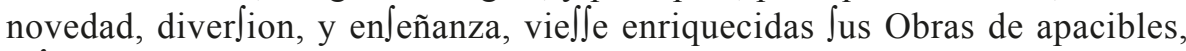
difcretas, y admirables imitaciones de los hechos humanos» (1750: [14]); o «todos los Poetas, que de mucho tiempo à efta parte, mantienen, è ilu tran el

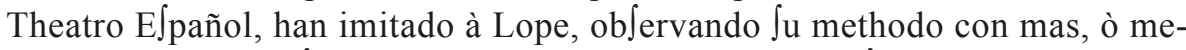
nos fuerza. Sus milmos contemporàneos emulantes, defpreciaron las reglas, tomando, en mucha parte, Jus lecciones» (1750: 171). Los elogios al Fénix son una constante en el libro. 
Uno de los trabajos que nos han servido como fuente, difiere de los demás pues solo menciona a Lope de Vega en algunas ocasiones, pero no incluye importantes noticias sobre su vida o su obra, ni inserta valoraciones de su producción. Se trata del Manifiesto por los Teatros españoles, y sus Actores, que dictó la imparcialidad; y se presenta al publico, a fin de que lo juzgue el prudente. Compuesto por Manuel Garcia de Villanueva, Parra, Hugalde, Moya, y Madrid, \&c. Primer Galan en la Compañía de Eusebio Ribera, editado «En la Imprenta de la Viuda de Ibarra, MDCCLXXXVIII, Madrid, Con licencia».

De todos modos, en el conjunto de libros que hemos manejado, lo habitual es que no falten referencias a Lope y sus creaciones, y que en la inmensa mayoría podamos encontrar alabanzas a sus aportaciones, aunque puedan ser señalados aspectos que a los respectivos autores le puedan parecen vituperables. Así, Juan José López de Sedano, en el tomo III de su Parnaso Español, escribe: «LOPE fue verdadero monstruo de la naturaleza. No se cuenta de Poeta alguno entre los antiguos y modernos que haya escrito tanto, porque no se cuenta de otro que haya tenido igual fertilidad ni abundancia de talento» (1770: $\mathrm{x}$ ).

El Ensayo historico-apologetico de la literatura Española contra las opiniones preocupadas de algunos Escritores modernos Italianos. Disertaciones del Señor Abate Don Xavier Lampillas incluye afirmaciones como «Podemos estar agradecidos al famoso Lope de Vega, que ha logrado de Betineli el honor de hacerle nombrar repetidas veces á la nación Española, no sin nota de parcialidad; porque suenan frequentemente los Españoles en ciertos parages de sus libros, y algunas veces con poca oportunidad» (1778-1781: III, 37); en poesía burlesca «Merece ser coronado por Principe en esta clase el famoso Lope de Vega, autor de la Gatomaquia, poema épico burlesco, dividido en siete cantos, ò silvas, del qual escribe Baillet haber excedido a quanto se ha escrito de este genero, comenzando desde la Batracomiomachia de Homero. Con efecto, si Lope de Vega hubiera sido tan feliz en la Epica grave, como lo fué en lo heroyco jocoso, sin duda hubiera dejado atràs aun al Principe de aquella» (1778-1781: III, 137); o «la revolucion ocasionada por Lope de Vega y sus sequaces en el teatro còmico, constituye la época de la nueva comedia, adoptada despues por las demas naciones, y que en medio del crecidisimo numero de comedias desarregladas y monstruosas que se vieron en nuestras tablas en aquellos tiempos, hay algunas, y no pocas, que por la regularidad, por la expresion de las imagenes, por la invencion ingeniosa, por el enlaze natural, por el dulce y elegante estilo son creìdas dignas de la imitacion de los mejores Dramaticos, y elevaron el teatro Español sobre el de las demàs naciones hasta los tiempos de que se trata» (1778-1781: IV, 167).

Juan Andrés, en el t. 4 de su Origen, progresos y estado actual de toda la Literatura, al igual que Vicente García de la Huerta, en su prólogo del Theatro 
Hespañol, respetan y exhiben opinión positiva, en general, de Lope de Vega aunque, el primero, en una ocasión, matiza: «En una cosa encuentro particular igualdad entre estos dos poetas [Lope de Vega y Dryden], que es en haber conocido ambos las leyes del buen teatro, $y$ en haberlas despreciado por condescender con el gusto del pueblo» (1997-2002: 236).

Adolfo Federico, conde de Schack, escribe sobre las labores del Fénix, en su Historia de la literatura y del arte dramático en España: «desde 1588 al 1590 [...] entonces comenzó Lope de Vega á ejercer en el teatro influencia exclusiva, y la revolución que produjo en la literatura dramática, puesto que los mismos contemporáneos de Lope confiesan, que, en virtud de dichas causas, empezó una nueva época del teatro español, llamada por ellos su edad de oro» (1845: II, 185); «todo lo suyo [de Lope] no es de igual valor; si la rapidez, con que escribía, ha perjudicado á la plena perfección de algunas de sus composiciones, recordamos de nuevo el número prodigioso de ellas, y consideramos que ha escrito más dramas buenos que otro cualquier poeta dramático del mundo conocido, y que, por consiguiente, merece que se extienda el manto del olvido sobre los defectos de todos los demás» (1845: II, 408); «Superar á Lope de Vega en riqueza de inventiva, ó rivalizar siquiera con él en este terreno, ni Calderón ni ningún otro mortal podría esperarlo» (1845: IV, 213); «ningún poeta de la antigüedad ni de los siglos más modernos puede compararse á Lope de Vega, porque á él debe su existencia la comedia española, la cual, descartando de ella algunos defectos insignificantes, es, sin disputa, por su gran belleza, la primera del mundo» (1845: V, 200).

En la misma línea se sitúa la Historia de la Literatura Española de George Ticknor: «IMPOSIBLE es hablar de Cervantes y calificarle, como lo hemos hecho, del mayor genio literario que ha producido España, sin recordar á su rival Lope de Vega, tan superior á él en fama contemporánea, y que llegó en su tiempo á alcanzar tal nombradia cual ningún otro escritor español antiguo ú moderno ha logrado después; pudiendo al propio tiempo competir con las mayores que ha habido en otros países» (1851-1856: II, 256); «Lope tomó el teatro en el estado en que le halló, y en vez de acomodarlo á una teoría anterior ó de tomar por modelo lo que en su tiempo existia, miró como el objeto principal de sus trabajos el interesar y satisfacer el gusto del público de su época; objeto que declara con la mayor claridad en su Arte nuevo de hacer comedias» (1851-1856: II, 316); «dotado al mismo tiempo de ingenio privilegiado, llegó á ser el fundador del teatro nacional, que puede decirse ha continuado desde entonces su marcha apoyado en los cimientos en que él le colocó» (1851-1856: II, 316); «Pero este mismo sistema (si es que podemos aplicar este nombre á lo que mas bien debe llamarse instinto) supone necesariamente que Lope sabia deleitar á su auditorio con una variedad admirable de formas dramáticas; razón por la que encontramos en sus comedias 
tal diversidad de tono, espíritu, intención y estructura, que se ve claramente con cuánta facilidad las adaptaba á las alteraciones inseguras del gusto popular, complaciéndole y agradándole de continuo» (1851-1856: II, 317); «Lope entendía perfectamente el arte de captarse el favor y voluntad del público, y que supo fundar y levantar el edificio de su fama como primer poeta dramático de su tiempo» (1851-1856: II, 392); los poemas «de Lope de Vega, de que ya hablamos en otro lugar, produjeron la misma turba de imitadores que todas sus demás poesías populares» (1851-1856: III, 247); «el ancho campo de extravagancias que el ingenio ameno y variado de Lope abrió á sus contemporáneos» (1851-1856: IV, 49), etc.

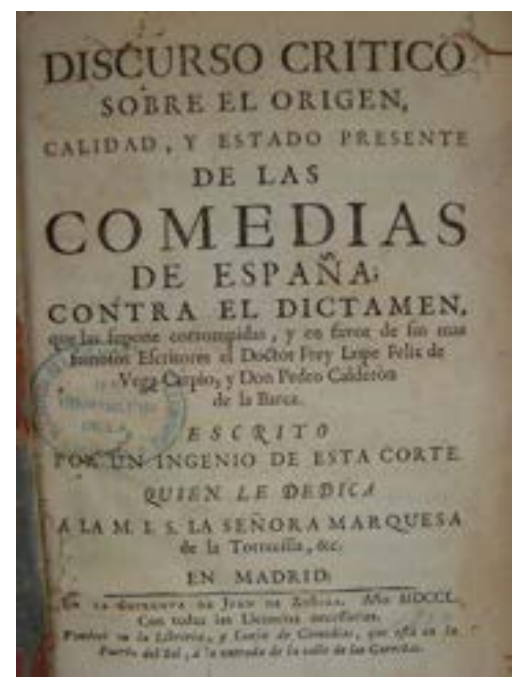

[IMAgEn 2]. Anónimo (1705). «Portada». Discurso crítico sobre el origen, calidad y estado presente de las comedias de España, [...] en favor de sus más famosos escritores, el Dr. Frey Félix Lope de Vega Carpio y D. Pedro Calderón de la Barca. Madrid: Imprenta de Juan de Zúñiga.

\section{LAS APORTACIONES DE SIGLO Y MEDIO DE HISTORIOGRAFÍA LITERARIA}

Dos de los aspectos tratados por nuestras fuentes documentales en sus páginas son la biografía y la producción literaria de Lope de Vega. Ellos, con sus indagaciones y recopilaciones de datos y noticias, trazan, sobre estos temas, el primer boceto científico, que la historiografía literaria española de la Ilustración y del primer Romanticismo van a legar a los estudiosos posteriores, para proporcionarles una base sólida que ellos se pueden encargar de perfeccionar, ampliar y completar.

En la biografía de Lope de Vega, los críticos y estudiosos que nos ocupan transmiten noticias, en su mayor parte, extraídas de la Fama póstuma a la vida y muerte 
del Doctor Frey Lope Félix de Vega Carpio de Juan Pérez de Montalbán. Los datos sobre la vida del Fénix no figuran en todos los libros que hemos utilizado. Solo los recogen Juan José López de Sedano, en su Parnaso Español (1770: III, vii-xv); Manuel García de Villanueva Parra Hugalde, en su Origen, épocas y progresos del teatro español (1802: 273-275); Joseph Antonio Álvarez y Baena, en Hijos de Madrid, Ilustres en Santidad, Dignidades, Armas, Ciencias y Artes (1790: III, 350363); Jean Charles Léonard Simonde de Sismondi, en su Historia de la literatura española desde mediados del siglo XII hasta nuestros días (1813: II, 24-47); Antonio Gil de Zárate, en su Manual de Literatura (1844: 170-229); Adolfo Federico, conde de Schack, en su Historia de la literatura y del arte dramático en España (1845: II, 303-342 y 343-385); y George Ticknor, en el t. 2 de su Historia de la Literatura Española (1851-1856: II, 256-282, 283-301, 302-330, 331-349 y 350-419).

Las informaciones sobre la vida de Lope que los autores enumerados en el párrafo anterior, como conjunto, aportan, son las que resumimos a continuación. Establecen sus orígenes familiares, su ascendencia hidalga; su nacimiento en Madrid; los miembros de su familia; su bautizo (Joseph Antonio Álvarez y Baena, en el tomo 3 de sus Hijos de Madrid, Ilustres en Santidad, Dignidades, Armas, Ciencias y Artes, incluye textualmente su registro parroquial [1790: III, 350]); su formación básica (a los cinco años ya leía en español y en latín); sus estudios, antes de los diez años, en el Colegio Imperial de Madrid de Gramática, Retórica y, quizá, Poética; su huida, con un amigo suyo, de Madrid hasta Astorga, lugar en el que se arrepintieron y se volvieron; su entrada al servicio de Gerónimo Manrique, obispo de Ávila; sus primeras comedias; sus estudios universitarios en Alcalá de Henares; la obtención del título de Bachiller; la ampliación de sus estudios en materias como Matemáticas, Francés, Italiano, o Portugués; su servicio, como secretario, al duque de Alba, don Antonio, que se convirtió en su amigo y protector; la composición de la Arcadia $^{24}$; su matrimonio con Isabel de Urbina; su estancia en Valencia ${ }^{25}$; su participación en la Gran Armada de Felipe II enviada contra

24 De ella escribe Joseph Antonio Álvarez y Baena, en sus Hijos de Madrid, «en cuyas prosas y versos, superiores á las del Sanázaro, disfrazó con fingidos nombres é historias, verdaderos sucesos y lances de amor, pertenecientes á aquel Señor [el duque de Alba] y otros» (1790: III, 353).

25 Joseph Antonio Álvarez y Baena, en sus Hijos de Madrid, la relata así: «Vivia con envidiable paz y contento en este estado [su matrimonio con Isabel de Urbina], quando la suerte, que trata rígidamente a los mayores ingenios, le proporcionó un azar, que le originó el sinsabor de una larga y sensible ausencia. Vivia en esta Corte un detractor de vidas y personas, y dió en calumniar y mofar la de Lope en algunas conversaciones. No tuvo éste otro despique que pintarle con mucha gracia, y hacerle ridículo en un Romance, que fué causa de que el maldiciente desafiase al Autor, que supo emendarle con bizarría, y castigar con sangre su atrevimiento. Viose Lope con este motivo en la cárcel, de donde le sacó la astucia ó valor de Claudio Conde, á quien llama su intimo Amigo en la Dedicatoria que le hace de la Comedia Buscar su propia desdicha, una de las de la parte 15, y en la precision de dexar ambos la patria, y refugiarse en Valencia, en donde pagó Lope la fidelidad de Claudio con igual beneficio de extraerle de la Torre de Serranos, que es una 
Inglaterra, en la que murió su hermano alférez; su regreso a Madrid; su entrada al servicio de distintos nobles, como el marqués de Malpica, y, después, conde de Lemus; la muerte de su esposa; su boda con Juana Guardo, con quien tuvo dos hijos, Carlos (muerto a los siete años) y Feliciana (que casó con Luis de Usategui); el fallecimiento de Juana Guardo; sus relaciones con María de Luxan, con quien tuvo a su hija Marcela, que fue religiosa con quince años en las Trinitarias Descalzas, y a su hijo Lope Félix, que participó en la Justa Poética á la Beatificación de San Isidro, con catorce años; su ordenación como sacerdote; su constante dedicación a la poesía a lo largo de su existencia; su pertenencia a la Congregación del Caballero de Gracia; los cargos que desempeñó como sacerdote (capellán de los carmelitas descalzos, y de las Trinitarias Descalzas...); los honores que le concedió el papa Urbano VIII, a quien dedicó La corona trágica (un hábito de la Orden de Caballería de San Juan, que le otorgó el tratamiento de «frey»; el doctorado en Teología por la Universidad de La Sapienza de Roma; «Promotor-Fiscal de la Reverenda Cámara Apostólica, y el de Notario escrito en el Archivo Romano; á que añadió el Tribunal de la Santa Inquisicion el de Familiar» [1790: III, 357-358]); su correspondencia con los principales hombres del momento (miembros de la nobleza; el cardenal Barberini y otros prelados, embajadores...); su enfermedad; su testamento, hecho ante Francisco de Morales y Barrionuevo, el 25 de agosto de 1635; su muerte en Madrid, el 27 de agosto de 1635, a los 73 años; las fastuosas honras fúnebres que le dedicaron; su entierro popular multitudinario; su descanso eterno en la iglesia madrileña de San Sebastián; los actos organizados, tras su deceso, en Madrid en su memoria.

Sobre la producción legada por Lope de Vega a la posteridad, en prácticamente todas fuentes utilizadas hallamos referencias y opiniones sobre sus obras. Solo el antes mencionado escrito Manifiesto por los Teatros españoles, y sus Actores de Manuel García de Villanueva, se muestra más parco en la inclusión de datos sobre este aspecto. En todas las obras, no observamos un intento de elaborar un corpus más o menos completo de las creaciones del Fénix. Cada autor destaca unos textos u otros según sean sus intereses en cada parte de su trabajo. El más exhaustivo en enumerar obras de Lope es José Antonio Álvarez y Baena, en sus Hijos de Madrid, Ilustres en Santidad, Dignidades, Armas, Ciencias y Artes. Los demás hablan de grupos de obras, como sus romances, sus poemas, su teatro, sus comedias, sus autos. O hablan de composiciones aisladas. Pero no suelen enumerar títulos con ánimo de exhaustividad. En todo caso, en mayoría de las fuentes manejadas,

de las cárceles de aquella Ciudad, adonde le habian llevado sus travesuras. Allí permaneció Lope algunos años gozando de la natural delicia de aquella tierra, y de las cortesías y aplausos de sus naturales. El amor de la patria y la aficion á su esposa le restituyéron al seno y brazos de ambas con el mayor contento, que desvaneció la muerte de ésta, sucedida antes de un año en el de 1588 , á tiempo que él cumplia los 26 de su edad» (1790: III, 353-354). 
predominan los juicios sobre parcelas de la producción del Fénix sobre las relaciones de sus escritos concretos.

El corpus de obras que aporta José Antonio Álvarez y Baena es el siguiente: la Vega del Parnaso, el Laurel de Apolo (citadas en el t. 1 de sus Hijos de Madrid); Jerusalem conquistada, El leal criado, Rimas humanas y divinas del Licenciado Tomé de Burguillos (t. 2); la Arcadia, prosas y versos, Isidro, Poema Castellano, La hermosura de Angélica, Rimas humanas, Dragontea, El Peregrino en su patria, Rimas de Lope de Vega Carpio, La Jerusalem Conquistada. Epopeya trágica, Soliloquios amorosos de un alma á Dios, Rimas Sacras, Triunfo de la Fe en los Reynos del Japon por los años de 1614 y 1615, Justa Poética, y alabanzas justas que hizo la insigne Villa de Madrid al Bienaventurado San Isidro en las fiestas de su Beatificacion, La Filomena, La Circe con La mañana de San Juan, La Rosa Blanca, varios versos, tres Novelas, dos Cartas en prosa, una sobre la Nueva Poesía, y otra Comentario de un Soneto suyo, Triunfos divinos, con otras Rimas Sacras, y la Virgen de la Almudena, Poema Histórico, Romancero Espiritual para reglarse el alma con Dios, con las Estaciones de la Via-Crucis, Corona Trágica, vida y muerte de la Serenisima Reyna de Escocia María Estuarda, Laurel de Apolo, La Selva sin Amor, Egloga, y otros versos, La Dorotea, Rimas Humanas y Divinas del Lic. Tome de Burguillos, con la Gatomacbia, y otras Rimas Divinas y humanas, La Vega del Parnaso «Contiene El siglo de Oro: versos heroycos al nacimiento del Príncipe: Egloga Panegirica al Epígrama del Infante D. Cárlos», «Cancion al Serenísimo Señor Infante D. Fernando de Austria, que le dedicó la Congregacion de Sacerdotes Naturales de Madrid», «Versos á la primera fiesta de Palacio Nuevo: á la venida a España del Duque de Osuna», Eliso, «Egloga en la muerte del P. Fr. Hortensio Paravicino», Egloga á Claudio, «Huerto deshecho, metro lírico», Oracion en el certamen de los Recoletos, Sentimientos á los agravios de Christo, «Amarilis y Filis, Eglogas (la 2. ${ }^{\text {a }}$ es á la décima Musa Doña Bernarda Ferreyra de la Cerda, Señora Portuguesa, que se imprimió en Madrid año 1635, en 12. $\left.{ }^{\circ}\right) »$, «Isagoge á los Reales Estudios del Colegio Imperial», «Felicio, Egloga piscatoria a la muerte de su hijo D. Lope Felix del Carpio y Luxan», «La Pira Sacra en la muerte de D. Gonzalo Fernandez de Córdoba, con otras piezas pequeñas y 8 Comedias», «Fiestas del Santísimo Sacramento, repartidas en 12 Autos Sacramentales, con sus Loas y Entremeses, que recogió su amigo el Lic. Joseph Ortiz de Villena» (1790: III, 365-369).

José Antonio Álvarez y Baena incluye también, en este tomo 3 que acabamos de citar, una relación de ediciones de obras de Lope aparecidas en el siglo XVIII, y una aclaración sobre sus textos:

De todas estas obras ha hecho D. Antonio de Sancha, Impresor en esta Corte, una edicion de 21 tomos en $4 .^{\circ}$ á que dió principio en 1776, por subscripcion, con este 
título: Coleccion de las obras sueltas, así en prosa, como en verso, de D. Frey Lope Felix de Vega Carpio, \&c. y en ella se han aumentado algunas cosas, que no se hallan en los tomos antecedentes, y son: / En el tom. 8..$^{\circ}$ quatro Novelas. / En el 13 algunas Rimas Sacras, que imprimió el conde de la Saceda en Madrid año 1747, en 8. / Y Contemplativos discursos á instancia de los Hermanos Terceros de San Francisco, y forma breve de rezar el Santo Rosario. / En el 17 varios versos y prosas esparcidos en las obras de otros AA. en su elógio y aprobacion; dos Sonetos y dos Cartas ineditas, y algunos Romances, que se hallan en el Romancero General. / Tambien se comprehenden en estos 21 tomos La Fama Póstuma de Lope, que publicó el Dr. Juan Perez de Montalvan, Madrid 1636, en 4. ${ }^{\circ}$, las Exêquias Poéticas, que le hiciéron en Italia, una Egloga que escribió el Dr. Juan Antonio de la Peña, con los consonantes forzados de la de Lope, intitulada Filis, que por mi diligencia se ha incluido en el tomo 19 de esta Coleccion, como otras varias piezas del mismo Lope. / Sin embargo del gran cuidado con que se recogieron para esta impresion las obras de este insigne Autor, se echan ménos en ella las siguientes. / Canciones Angélicas 20, / Coloquios Pastorales en alabanza de la Concepcion de Nuestra Señora. / Relacion de las fiestas hechas en Toledo al Nacimiento de Felipe IV. [...] Esta podrá ser la cancion, que á este asunto se halla en la Vega del Parnaso. / Y un Memorial impreso al Señor Felipe III á efecto de que no permitiese que hicieran el retrato de S. M. los malos Pintores, de que hace mencion Gil Gonzalez en la Vida de este Monarca, y de la respuesta que dió el Rey, diciendo: Dexadlos ganar de comer, que ya que pintan nuestro rostro, no pintan nuestras costumbres. I Autos Sacramentales compuso mas de 400, de que solo se hallan impresos 12 por el Lic. Joseph Ortiz de Villena, como queda dicho, y 4 en el Peregrino. / Comedias 1800, de que solo se conocen 25 tomos en $4 .^{\circ}$ muy raros, impresos en Valencia, Valladolid, Barcelona, Zaragoza, y la mayor parte en Madrid desde el año de 1609, hasta el de 1647. El curioso que quiera saber los títulos de todas estas piezas, vea á D. Nicolas Antonio en el artículo de Lope. / Y no obstante que no se dedicó a los metros latinos, porque decia que cada uno habia de escribir en su lengua materna, consta de la dedicatoria ya citada de la Comedia Virtud, pobreza y muger, que escribió una Egloga Piscatoria latina intitulada Amarilida, de que inserta allí un fragmento en loor del Caballero Marino que pondré aquí para que se vea la facilidad y destreza con que hubiera manejado la Poesía Latina, sino hubiese sido de aquella opinion [copia el fragmento, p. 371]» (1790: III, 369-371).

En el resto de los estudiosos examinados, las obras mencionadas de Lope de Vega son las siguientes. En Nasarre no se halla relación de escritos del Fénix. Se menciona el Arte nuevo (1749: 23), y sus comedias en general, sin detallar títulos. Montiano y Luyando cita algunas comedias concretas, como El duque de Viseo, Roma abrasada, La bella Aurora, La inocente sangre, El marido más firme, El castigo sin venganza; y algún texto suelto: El peregrino en su patria, " $\int \mathrm{u}$ Arte de Comedias». Y todo en su Discurso primero. En el Discurso crítico sobre el origen, calidad y estado presente de las comedias de España de Tomás de Erauso y Zavaleta, imperan los juicios y valoraciones 
generales sobre la obra de Lope, al igual que en Juan Andrés. Juan José López de Sedano, en su Parnaso español, recuerda los sonetos de las Rimas de Burguillos, La gatomaquia (t. 2); la Corona trágica, su Poesía lírica, su Poesía cómica, «mil ochocientas y tantas Comedias, y más de quatrocientos Autos Sacramentales» (1749: x), Égloga a Claudio, El Siglo de Oro, la égloga Amarilis, una canción, una elegía, La pulga, Soneto en culto (t. 3); el Laurel de Apolo, la égloga Filis (t. 4); una égloga, un epigrama, una canción, un soneto, un soneto de Burguillos (t. 8); el Laurel de Apolo, un texto dedicado a la muerte de Baltasar Elisio de Medinilla (t. 9).

Lampillas incluye el Arte nuevo, la Gatomaquia (t. 3); comedias que, según su opinión destacan: «El villano en su rincon-La Esclava de su Gálan-El Domine Lucas-la Dama melindrosa-la Dama boba-la Ilustre fregona-el Rico Avariento» (1778-1781: 172, n. *) (t. 4). García de la Huerta recuerda el Arte Nuevo. En el Manifiesto por los Teatros españoles, y sus Actores de Manuel García de Villanueva, no se mencionan obras específicas, aunque sí en Origen, épocas y progresos del teatro español del mismo escritor, en donde se detectan menciones de creaciones como El Duque de Viseo, Roma abrasada, La bella Aurora, El Castigo sin venganza, La inocente sangre, El Marido mas firme, o el Arte Nuevo, cuyo texto reproduce entre las páginas 275 y 285 . Casiano Pellicer es parco también en la numeración de obras concretas. Menciona sus comedias, la Arcadia (t. 1). Bouterwek habla del «Nuevo arte de hacer comedias» (1778-1781: 178). Simonde de Sismondi cita Las doncellas de Simancas, Las almenas de Toro, el Arte Nuevo, el Laurel de Apolo, «Obras sueltas de Lope de Vega» (1778-1781: 385). En Antonio Gil de Zárate aparece el Arte Nuevo (t. 1); menciona sus comedias, que clasifica siguiendo a Alberto Lista (1844: 204), su poesía popular (t. 2), pero predominan sus juicios y opiniones sobre el autor madrileño.

Leandro Fernández de Moratín, en sus Orígenes del teatro español, utiliza más al Fénix como referente y como autoridad, quizá porque se ocupa de piezas dramáticas anteriores á Lope de Vega. El conde de Schack recuerda textos como El bastardo Mudarra, Las mocedades de Bernardo del Carpio, Las almenas de Toro, La Dorotea (t. 1); el «Nuevo arte de hacer comedias» (1830: 268), El Isidro, El peregrino en su patria (t. 2); el Laurel de Apolo, comedias (t. 4). En su Historia de la literatura y del arte dramático en España, predominan también los juicios críticos y las opiniones sobre Lope, antes que la enumeración exhaustiva de su producción. En la Historia de la Literatura Española de George Ticknor, se recuerdan poemas suyos, romances, sonetos, la «Justa Poética de San Isidro» (1851-1856: I, 471, n. 19); La Dorotea, La Arcadia, los poemas a Belisa, El Isidro, La hermosura de Angélica, La Dragontea, El peregrino en su patria, Arte nuevo de hacer comedias, Jerusalen conquistada, Los pastores de Belén, Romancero espiritual, La Gatomaquia, 
La Filomena, La Circe, Mañana de San Juan, Triunfos divinos, la Corona trágica, el Laurel de Apolo, La Dorotea, el Siglo de oro, El verdadero amante, La pastoral de Jacinto, sus comedias de capa y espada, La hermosa fea, Dineros son calidad, Las bizarrías de Belisa, La esclava de su galán, El perro del hortelano, El acero de Madrid, La boba para los otros y sabia para sí misma, El premio del bien hablar, Por la puente Juana, El anzuelo de Fenisa, El ruiseñor de Sevilla, Porfiar hasta morir, Roma abrasada, El castigo sin venganza, La mañana de San Juan (1851-1856: II).

Los juicios y valoraciones de las creaciones de Lope son una constante en todos los escritos consultados. A veces, positivos; a veces, negativos. Las opiniones sobre el Fénix mayoritariamente suelen girar en torno a su teatro, aunque también hallamos comentarios sobre su poesía y su novelística. Juicios negativos sobre Lope de Vega figuran, sistemáticamente en la Dissertacion de Blas Nasarre. Este historiador de la literatura lo juzga «primer corrompedor del Theatro». Sobre su arte dramático indica:

El artificio, y afeyte con que hermo $\int e a$ los vicios, es capaz lin duda de corromper los corazones de la juventud. A mas de que la ingenio $\int_{i d a d}$ de la maraña es cali Jiempre inverofimil; y la diccion elegante, y fluida, no corre $\int$ ponde por Jus elevados conceptos, y afectadas erudiciones, à efte Poema: Jerian para lo lyrico, y trágico aùn dignos de correccion. Los anacronimos, la falta de Geographia, de Mythologia, de Hiftoria, Je dexan vèr à cada pa $\iint_{0}$; y quando quiere hablar de las artes,

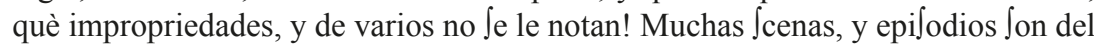
todo impertinentes, y nada intere $\iint a n$ à la accion, ni à los oyentes. Lo que llaman

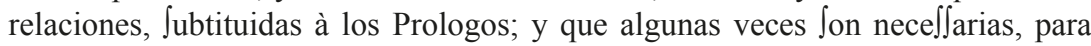
que los oyentes entiendan la Comedia, y fe pongan en la expectacion, y pendientes

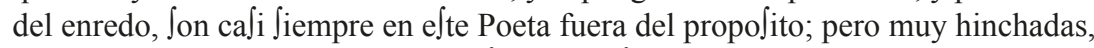
$\mathrm{y}$ altas, y con pinturas impertinenti $\int$ simas, en $\int$ artadas en metaforas enormemente atrevidas (1749: 25-26).

En la misma línea se sitúan los dos Discursos sobre la tragedia de Agustín Montiano y Luyando, aunque, en sus afirmaciones sobre el teatro del Fénix se muestran algo más benévolo que Nasarre. Él reconoce, por ejemplo, en el primer Discurso, que «los verJos de Lope llevan configo generalmente la executoria del buen lenguage, y de los mejores conceptos» (1749: 50). Pero, aun así, lo culpa de la mala calidad del teatro español:

[Los autores] olvidaron, cali en un todo, las reglas antiguas; y entregados $\int$ in re erva, à las que autorizaba la moda, y el credito de Lope de Vega, à defpique de la razon; Jucedieron las nuevas compoficiones: que no Jon en la realidad Comedias, por

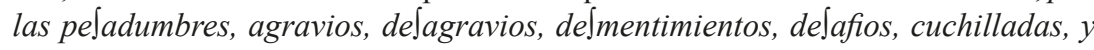




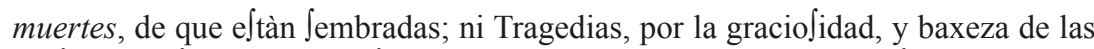

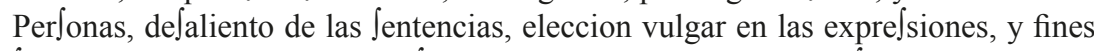
fiempre alegres, con que las vilten. Las menos denegridas con e f tas tachas, aun no las coloca $\mathrm{Ca}$ fcales entre las Tragedias dobles: Jiendo afsi, que es lo milmo, que graduarlas de malas Tragedias (1749: 69).

En el Discurso II, se mantiene la misma línea:

Entre los que ocupan el mas diftinguido lugar, configuiò Lope de Vega hacer famo $\int a$ la confe $\int$ sion de $\int u$ error, que es buen te $\int$ timonio de $\int u$ elevado merito, ganar reputacion con lo propio que tantos la han perdido. No obltante, al verificarje (lo que fue muy de de luego para los Doctos) que las aventuras amorolas, principal, fino unico objeto de nue $\int$ tras Reprefentaciones, pegaban el contagio de $\int u$ libertad

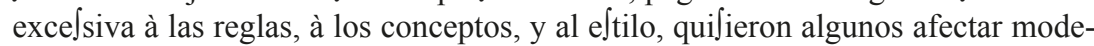
racion en Jemejantes licencias, ò poner coto à Jus perjudiciales efectos; $\mathrm{y}$ tomando algo de la Jeriedad Tragica, y mas de la alegria Comica, compufieron Tragicomedias, de $\int$ nudandolas halta del titulo de tales, por no efpantar al Vulgo, entregado ciegamente à los defordenes de la imaginacion, y del gufto (1753: 12-14).

En el extremo contrario se sitúa Tomás de Erauso y Zavaleta, quien, sobre el teatro de Lope, considera:

Son las Comedias de Epaña, y en elpecial las de los venerados Lope de Vega, Calderon, y Jus Imitadores, el mas dulce agregado de la Jabidurìa, de la discrecion, de

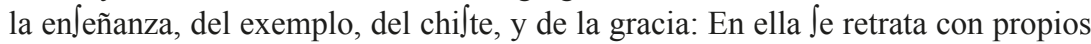
apacibles colorídos, el genio grave, pundonorò $\int o$, ardiente, agudo, Jutìl, con $\int t a n t e$, fuerte, y cavallero, de toda la Nacion. Se miran, y Je admiran exercidas, con la mayor delicadeza, todas las valentìas, frales, artificios, figuras, primores, y Jonoras filigranas del Idioma nue tro, aplaudido de todas las Naciones, por abundante, por facil, y harmoniofo (1750: [9-10]).

El resto de los autores se muestra más comedido. Ellos pueden reconocer errores y destacarlos, pero también se muestran dispuestos a destacar aspectos positivos en las creaciones del Fénix, y en su arte literario. Así, en el Parnaso español de Juan José López de Sedano, sobre La Gatomaquia, leemos:

[...] se debe estimar esta Obra por única y superior á todas las de su especie, tanto en nuestra Lengua, como en las estrañas. Agregase á esto el mérito, que ella tiene en sí, por todos los demás requisitos, que constituyen su perfeccion, porque en las pinturas ó descripciones abunda con mucha profusión y propiedad: en la moralidad es siempre grave: en la erudición abundante: en las digresiones extraordinariamente pródigo, y algunas veces dilatado. Este, si se puede llamar defecto, tiene por disculpa la propia abundancia y prodigiosa fecundidad de su robusto ingenio; y 
mucho mas en un Poema Épico, en donde son mas permitidos, y correspondientes estos ensanches. [...] Finalmente, en quanto á pureza, facilidad, y demás singulares prerrogativas del estilo y de la sentencia, basta por recomendación el solo nombre del Autor (1770: II, XVIII-XIX).

De la producción de Lope se resalta:

LOPE fue verdadero monstruo de la naturaleza. No se cuenta de Poeta alguno entre los antiguos y modernos que haya escrito tanto, porque no se cuenta de otro que haya tenido igual fertilidad ni abundancia de talento. Los libros y tratados sueltos de Poesía Lírica, y en prosa impresos pasan de 50. Los tomos de Poesía Cómica son 26, y en ellos un mil ochocientas y tantas Comedias, y mas de quatrocientos Autos Sacramentales, que todos se representaron; y lo que sobre todo esto admira mas, es lo que afirma en su Égloga á Claudio, pues hablando de todas sus Obras, y suponiendo que todas las mas las imprimió, dice, que no es mínima parte, aunque es exceso, de lo que está por imprimir, lo impreso. Finalmente consta por deposición del mismo LOPE, que salia á cinco pliegos cada dia, que multiplicados por los de los años que vivió, salen 133. 225 pliegos $\left(^{*}\right)[(*)$ Hecha ahora por curiosidad la cuenta por una prudente regulación de los versos que pueden corresponder á cada pliego, y descontados los de los pocos tratados que escribió en prosa, sale que compuso en su vida veinte y un millones trescientos y diez y seis mil versos.]: fecundidad enorme é inaudita, que en su clase no ha tenido egemplo hasta ahora, á la qual correspondió su natural afluencia y facilidad para los versos, única y característica en él, sobre quantos Poetas tiene la Nación, en tan supremo grado, que compuso muchas Comedias, en que solo gastaba 24 horas de tiempo; y alguna en menos de cinco; y finalmente escribía el verso corriente y sin intermisión, como se escribe la prosa; y algunas veces, lo que admira mas, con la misma lima y pulimiento que si hubiese sido muchas veces retocado (1770: $\mathrm{x}$-xi).

\section{Pese a todo, López de Sedano reconoce:}

entregado todo en manos de su ingenio y de su fecundidad prodigiosa, descuidó muchas veces de dar su parte á la imitación y al arte; y aunque este don, como la prenda principal de un Poeta, sea su mas gloriosa disculpa en las meras producciones del ingenio, pero no lo puede ser en las obras Didácticas, Dramáticas, y otras especies de las en que debe obrar el arte junto con la naturaleza. Esta es la causa por qué se han hecho, y sobre que han recaído en diversos tiempos tantas críticas á sus Obras, especialmente en las clases Épica y Dramática. En todas quantas veces egercitó su pluma en Poemas de la primera especie se vé claro el abandono de las reglas y de la imitación, aunque al mismo tiempo se notan las infinitas preciosidades que se ocultan entre estos defectos (1770: III, xi-xii).

Xavier Lampillas elogia todas las parcelas de la producción de Lope. Así, por ejemplo, dice: «en las antiguas Novelas Españolas. En ellas se hicieron famosos 
Lope de Vega, Juan Pérez de Montalvan, Alfonso Castillo Solórzano, y la erudita Doña Maria de Zayas» (1778-1781: III, 172); sobre su poesía burlesca: «Merece ser coronado por Principe en esta clase el famoso Lope de Vega, autor de la $\mathrm{Ga}$ tomaquia, poema épico burlesco, dividido en siete cantos, ò silvas, del qual escribe Baillet haber excedido a quanto se ha escrito de este genero» (1778-1781: III, 137); como traductor: «No faltan à nuestra poesía algunas dulcisimas Elegias de Tibulo, y de Catulo, traducidas por Villegas y Lope de Vega» (1778-1781: III, 147). Pero reconoce que,

la revolucion ocasionada por Lope de Vega y sus sequaces en el teatro còmico, constituye la época de la nueva comedia, adoptada despues por las demas naciones, y que en medio del crecidisimo numero de comedias desarregladas y monstruosas que se vieron en nuestras tablas en aquellos tiempos, hay algunas, y no pocas, que por la regularidad, por la expresion de las imagenes, por la invencion ingeniosa, por el enlaze natural, por el dulce y elegante estilo son creidas dignas de la imitacion de los mejores Dramaticos, y elevaron el teatro Español sobre el de las demàs naciones hasta los tiempos de que se trata (1778-1781: IV, 167).

Juan Andrés alaba los escritos de Lope:

¿Dónde se encontrarán versos mas armoniosos y suaves, estilo mas fluido y nítido, y mayor copia de sentencias y de palabras, que en las canciones del tan celebrado Lope de Vega? ¡Oxalá no hubiera querido mancharlas con sutilezas, afectaciones y puerilidades! que seguramente hubiera sido Lope el principe de los líricos españoles, y aun tal vez de todos los modernos. De mayor nobleza y sublimidad, y de casi igual facilidad de versificacion y nitidez de estilo puede gloriarse Quevedo; pero con harto mayores defectos (1782-1799: 387-388).

García de la Huerta se muestra más parco en alabanzas propias, aunque sí recoge elogios que escritores extranjeros dedicaron a Lope. Manuel García de Villanueva, en su Origen, épocas y progresos del teatro español, indica que con su teatro Shakespeare «fué el primero que empezó á ilustrar su nacion, así como en nuestra España Lope de Vega Carpio» (1802: 86). José Antonio Álvarez y Baena destaca la magnitud de la producción del Fénix, «Y no obstante esta multitud de obras, y la celeridad con que las trabajaba, parecieron tan bien, y se calificáron por tan perfectas, que el nombre de Lope fué antonomasia de lo bueno, diciéndose regularmente para atribuir esta calidad á una cosa que era de Lope» (1789-1791: III, 364).

No negaré que si hubiera escrito menos, hubiera escrito mejor: y que la crítica que se hace de muchas de sus obras, especialmente de las Comedias, es racional, y tiene grandes defectos sobre que recaiga; pero son tantas las virtudes que al mismo tiempo se ven en ellas, que no hay hombre, por mas severo que sea, que no trocara todo quanto hace y 
puede hacer sin perder de vista el arte y el juicio, por una pequeña parte de lo que hizo Lope de Vega aun con descuido. En verdad que no sé cómo hay quien lea sus obras, y le quede ánimo para disgustarse de ellas, ni zaherirlas (1789-1791: III, 365).

Sobre el volumen de sus textos, Casiano Pellicer se manifiesta en similares términos: «Lope de Vega bastaba para proveer á todos los Teatros de España; y no solo los proveia, sino que los autores de Comedias solo parece estimaban las de Lope» (1804: I, 156). Y sobre su obra dramática, reconoce que no sigue la preceptiva clásica, pero

No procedia Lope asi por ignorancia de las leyes teatrales; pues él mismo declara que desde los estantes de su libreria le daban voces y gritos Plauto y Terencio; sino porque desembarazado á la verdad de la sujecion y rigor de estas reglas, lozaneaba mas su ingenio y su imaginacion amena. Sin que se dexe de conocer que observando las leyes del Teatro antiguo, fundadas en la naturaleza, no hubiera por eso complacido menos al pueblo, aunque careciese de la gloria de ser padre y autor de tantos centenares de Comedias; pues cincuenta ó sesenta de ellas, escritas con el debido arte, $[\ldots]$ hubieran sido sin duda suficientes a haberle labrado con mas solidez el monumento eterno de su fama (1804: I, 165-168).

Pero, pese a todo,

el Teatro de Lope de Vega siempre será estimado, y siempre agradará por la pureza y suavidad del lenguage, por la viveza de su dialogo, por la propiedad de muchos de sus caracteres, por su invencion, por la exácta descripcion de las costumbres nacionales, por sus graves sentencias, por sus dichos festivos, y por sus frequentes agudezas (1804: I, 168).

Simonde de Sismondi, sobre el teatro de Lope señala que

Cualquiera que sea sin embargo, la rudeza y grosería de la mayor parte de los dramas de Lope de Vega, no puede decirse que sea su lectura enfadosa, ni que decaiga un punto el interes de la accion, causandonos la impaciencia y languidez, que las tragedias malas ó medianas de los poetas franceses de segundo órden nos inspiran. La rapidez de la accion, la multitud de acontecimientos, su complicacion estraordinaria, y la imposibilidad de preveer el desenlace, despiertan la curiosidad y le conservan casi siempre toda su viveza, desde la primera escena hasta el final de la obra (1813: 49).

No obstante,

La inconcebible fertilidad de Lope había sostenido su teatro, á pesar del poco cuidado y del poco tiempo, que empleaba en la correccion de sus dramas: pero sus demas poesías, producidas por un trabajo tan precipitado, son únicamente rudos, que casi nadie tiene valor para leer (1813: 76). 
En su Manual de Literatura, Antonio Gil de Zárate se muestra más crítico con el Fénix y sus escritos:

Lope de Vega, por no refrenar su imaginacion, produjo mucho, es cierto, asombró con su maravillosa fecundidad; mas no dejó ninguna obra perfecta, ninguna que no esté deslucida con defectos de gran cuenta. Flojo, desmayado, incorrecto, prosáico muchas veces, sus eminentes cualidades, que dirigidas por el arte, se hubieran fortalecido para mostrarse en todo su esplendor, dejeneraron en los vicios á que está siempre toda virtud cercada (1844: I, 9-10).

Pero, pese a ello, alaba «la pintura de los caracteres y en la forma del diálogo cuya imitacion es visible en los dramas que la siguieron hasta Lope de Vega» (1844: II, 33). Pues de los errores no juzga responsable a Lope, debido a que

Lope de Vega llegó cuando todos los vínculos del buen gusto y de la razon estaban rotos. Este grande hombre, poco á propósito ya por la fogosidad de su imaginacion y la inagotable abundancia de su vena poética para sujetarse á nimios preceptos, encontró el desórden entronizado. No se le debe, pues, achacar, como generalmente sucede, el desarreglo de nuestro teatro: antes bien, [...] fue un reformador en el sentido del verdadero drama; y si no hizo todo lo que debió y pudo, le dió mas naturalidad y sencillez al par que mas idealidad en los afectos y caracteres (1844: II, 142).

Además, el Fénix — piensa — no es responsable del desarreglo del teatro español del siglo XVII.

Lejos de esto, contuvo el desarreglo que sus predecesores habian introducido, rectificando el gusto que andaba perdido [...]. Mejoró infinito la parte relativa á la invencion de la fábula. [...] La fábula de Lope está llena de movimiento, de situaciones, de lances: hasta la esposicion misma se hace en accion y no en discursos, desterrándose la costumbre poco ingeniosa de las loas ó prólogos. A pesar de la multitud de lances, camina con mas claridad, con mas arte en la disposicion del argumento; y aunque se halla lejos de ser perfecta, rectificada la antigua confusion, y la exageracion ridícula, puede decirse que dió á la comedia mas regulares y sencillas formas (1844: II, 194-195).

Adolfo Federico, conde de Schack, en su Historia de la literatura y del arte dramático en España, elogia mucho a Lope. Habla de un «antes y después de Lope de Vega» (1845: I, 262, n. 1), y considera positiva su producción, y reconoce que, en el teatro, "iqué monstruoso abismo separa ya, aun á las primeras y más imperfectas obras de Lope, de las mejores de los que le precedieron! Por lo que hace á sus coetáneos, que emprendieron con él la misma senda, es lícito dudar si, á pesar de sus talentos sobresalientes, habrían fijado de una manera 
tan irrevocable el espíritu y la forma del drama, como él lo hizo. [...] Y en este sentido hemos de denominar sin escrúpulo á Lope de Vega fundador del teatro español» (1845: II, 430). Y por eso, continúa, «ningún poeta de la antigüedad ni de los siglos más modernos puede compararse á Lope de Vega, porque á él debe su existencia la comedia española, la cual, descartando de ella algunos defectos insignificantes, es, sin disputa, por su gran belleza, la primera del mundo» (1845: V, 200).

George Ticknor abarca varias parcelas de la producción de Lope de Vega. Indica que sus obras poéticas no es lo mejor de la producción del Fénix, ni lo más aceptado por el público, ya que, aunque «manifiestan sí gran talento original, mayor fuerza de inventiva y una facilidad de versificación maravillosa; pero rara vez se encuentra en ellas el verdadero y genuino espíritu poético. Pecan en general de abandono é incorrección, y casi todas ellas carecen de aquel carácter y fisonomía nacional en que naturalmente estriba la influencia positiva del ingenio sobre un pueblo entero» (1851-1856: II, 302); y añade,

si Lope no hubiera hecho otra cosa, su nombre no se hallaría hoy á la altura en que le contemplamos. Verdad es que sus novelas y églogas en prosa son mejores que sus composiciones épicas; que su poesía didáctica, sus elegías y sus epístolas son á veces excelentes; pero solo cuando huella á pié firme el suelo patrio, solo en sus glosas, letrillas, romances, canciones y coplas es cuando ostenta toda la gracia y lozanía de su ingenio. Al encontrarle en este terreno conocemos que nunca debió abandonarlo, como el campo en que, con las dotes extraordinarias de que le adornó naturaleza, pudo fácilmente alzar monumentos eternos á su nombre y á su gloria (1851-1856: II, 303).

Considera que lo mejor de sus textos se encuentra en su teatro, pues «dotado al mismo tiempo de ingenio privilegiado, llegó á ser el fundador del teatro nacional, que puede decirse ha continuado desde entonces su marcha apoyado en los cimientos en que él le colocó» (1851-1856: II, 316). Sus buenos éxitos se explican porque

Lope entendía perfectamente el arte de captarse el favor y voluntad del público, y que supo fundar y levantar el edificio de su fama como primer poeta dramático de su tiempo. Poco ó nada alteró los principios en que se apoyaba el teatro antiguo, si es que los tenía; él mismo dice que llevó adelante la comedia según la halló, sin aventurarse á seguir ciegamente las reglas del arte, porque si las hubiese observado, el público no hubiera hecho caso de él (1851-1856: II, 392).

En definitiva, tras examinar todos los trabajos en los que se estudia la figura y la obra de Lope de Vega, podemos hacernos una idea clara de cuál es la aportación 
que la crítica de la Ilustración y de la primera mitad del ochocientos lega a la posteridad referida al conocimiento de la biografía y de la producción literaria de Lope de Vega, y a la determinación del papel que ocupó, y ocupa, en las letras hispanas y universales.

Los estudiosos de los siglos XVIII y principios del XIX trazan el primer bosquejo relativamente completo, para las fuentes manejadas en su época, de la vida de Lope de Vega. Quedan esclarecidos sus orígenes familiares, los grandes hechos de su juventud, sus relaciones matrimoniales, sus años de ejercicio sacerdotal, los detalles de su fallecimiento y su sepelio, rodeado del fervor popular. También quedan enumerados los escritos principales que forman parte de su producción y la valoración que en esa época se hacen de ellos. Igualmente, queda especificado el papel que sus creaciones ocupan en la época en la que le tocó vivir. Se crean, en definitiva, las bases sobre las que se asienta el conocimiento científico de la biografía y de las composiciones lopistas; las bases que son transmitidas a los historiadores posteriores, y de las que estos parten en sus investigaciones historiográficas y críticas. Tal es la muy importante aportación que la primitiva historiografía científica española traslada a sus sucesores de la segunda mitad del ochocientos y de los siglos veinte y veintiuno.

Los críticos que suceden a los que hemos convertido en fuente de esta investigación, que ahora vamos concluyendo, no tuvieron que diseñar los fundamentos de cualquier trabajo serio sobre el conocido, ya desde su época, como «Monstruo de la Naturaleza», y como «Fénix de los Ingenios». Tuvieron principalmente que ampliar, matizar y corregir la base que habían heredado de sus predecesores. Así, en aspectos, por citar algunos ejemplos, como los pleitos y el destierro que hubo de padecer Lope por los amoríos de su juventud; o sus relaciones con Marta de Nevares; o su participación en la mal llamada «armada invencible»; o su auténtico papel en la historia de la comedia nueva; o la manera y el momento en que se fue efectuando la creación de su fórmula dramática que contó con tantos seguidores y tantas obras produjo; o el valor de sus poemas, la importancia de su novelística, etc. Son facetas de los estudios sobre el Fénix que abordaron maestros clásicos de la investigación y de la historiografía, como Marcelino Menéndez Pelayo (1919-1927), Atanasio Tomillo y Cristóbal Pérez Pastor (1901), Cayetano Alberto de la Barrera (1890), Hugo Rennert (1904), Américo Castro (1919), Karl Vossler (1932), José F. Montesinos (1951), Juan Manuel Rozas (1982), Rinaldo Froldi (1962), etc., y sus continuadores hasta la actualidad. Pero esa es otra historia que, tal vez, en otros trabajos, la crítica de nuestros días podría sentirse tentada a abordar. 


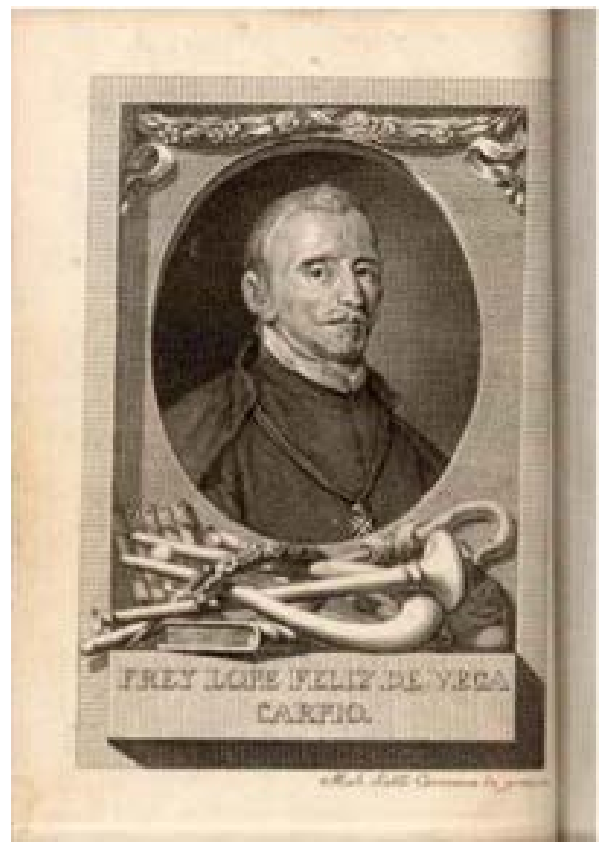

[Imagen 3]. Litografía de Lope de Vega. En Juan José López de Sedano (1770). El Parnaso Español. Madrid: Joachin Ibarra, t. 3. 


\section{BIBLIOGRAFÍA}

Barrera, Cayetano Alberto de la (1890). «Nueva biografía de Lope de Vega». En Obras de Lope de Vega, Marcelino Menéndez Pelayo (ed.). Madrid: Real Academia Española / Sucesores de Rivadeneyra.

Cañas Murillo, Jesús (1991). «Tipología de los personajes en el primer Lope de Vega: las comedias del destierro». Anuario de Estudios Filológicos, 14, pp. 75-95.

Cañas Murillo, Jesús (1992a). Blas Nasarre. Disertación o Prólogo sobre las comedias de España. Cáceres: Universidad de Extremadura.

CAÑas Murillo, Jesús (1992b). «Una nota sobre la polémica del teatro en el siglo XVIII: El Manifiesto por los teatros españoles y sus actores, de Manuel García de Villanueva». Anuario de Estudios Filológicos, 15, pp. 27-38.

Cañas Murillo, Jesús (1995). Honor y honra en el primer Lope de Vega: las comedias del destierro. Cáceres: Universidad de Extremadura.

Cañas Murillo, Jesús (1999). «Sobre la trayectoria y evolución de la comedia nueva». Káñina. Revista de Artes y Letras de la Universidad de Costa Rica, 23: 3, pp. 67-80.

Cañas Murillo, Jesús (2000). «Lope de Vega, Alba de Tormes y la formación de la comedia». Anuario Lope de Vega, 6, pp. 75-92.

Cañas Murillo, Jesús (2003). «Diez calas en el amor en el teatro del primer Lope de Vega: la configuración del tema en las comedias del destierro». En Felipe B. Pedraza Jiménez, Rafael González Cañal y Elena Marcello (eds.), Amor y erotismo en el teatro de Lope de Vega. Actas de las XXV Jornadas de teatro clásico de Almagro. Almagro, 9, 10 y 11 de julio de 2002. Almagro: Festival de Almagro / Universidad de Castilla-La Mancha, pp. 235-250.

Cañas Murillo, Jesús (2005). «Lope de Vega en los orígenes de la comedia nueva». Girasol. Revista de la Escuela de Estudios Generales de la Universidad de Costa Rica. Memoria del IX Congreso de Filología, Lingüística y Literatura «Joaquín Gutiérrez Mangel», n. ${ }^{\circ}$ extraordinario, pp. 51-64.

Cañas Murillo, Jesús (2009a). «En los orígenes del tipo del figurón: El caballero del milagro (1593), comedia del destierro del primer Lope de Vega». En Joaquín Álvarez Barrientos, Óscar Cornago Bernal, Abraham Madroñal Durán y Carmen MenéndezOnrubia (coords.), En buena compañia. Estudios en honor de Luciano García Lorenzo. Madrid: Consejo Superior de Investigaciones Científicas, pp. 159-169.

CAÑas Murillo, Jesús (2009b). «Sobre la primera "Segunda ImpreJsion” del Discurso sobre las tragedias españolas de Agustín de Montiano (Noticia bibliográfica)». Anuario de Estudios Filológicos, 32, pp. 41-59.

Cañas Murillo, Jesús (2010a). «Lope de Vega y la renovación teatral calderoniana». Anuario Lope de Vega, 16, pp. 27-44.

Cañas Murillo, Jesús (2010b). «El teatro español, y europeo, según Manuel García de Villanueva». En Victoriano Gaviño Rodríguez y Fernando Durán López (eds.), Gramática, canon e historia literaria. Estudios de Filología Española entre 1750 y 1850. Madrid: Visor, pp. 49-83.

Cañas Murillo, Jesús (ed.) (2013). Vicente García de la Huerta, Theatro Hespañol. Prólogo del Colector. Málaga: Universidad de Málaga, pp. 169-300. 
Cañas Murillo, Jesús (2015). «Pedro Calderón de la Barca en la polémica sobre Du Perron del siglo XviII: Nasarre, Montiano, García de la Huerta». Cuadernos de Ilustración y Romanticismo. Revista Digital del Grupo de Estudios del Siglo XVIII, 21, pp. 141-162.

CaÑas Murillo, Jesús (2017). «Teatros y sociabilidad en la Ilustración: la técnica del actor, y el montaje de los textos, según Montiano». En Eva María Flores Ruiz (ed.), Casinos, tabernas, burdeles: ámbitos de sociabilidad en torno a la Ilustración. Córdoba / Toulouse: Universidad de Córdoba / Universidad de Toulouse Jean Jaurès, pp. 79-104.

CAÑAS Murillo, Jesús (2019a). «En las bases para una historiografía literaria de la Ilustración: Juan Andrés, según Hervás, Sempere y Scotti». En M. Jo José Rodríguez Sánchez de León y Miguel Amores Fuster (eds.), La ciencia literaria europea en tiempos de Juan Andrés (1740-1817). Madrid: Visor, pp. 235-267.

CaÑas Murillo, Jesús (2019b). «En los orígenes de la historiografía literaria española: El Mester de Clerecía en la era de la Ilustración». En Jesús Cañas Murillo y José Roso Díaz (eds.), En los inicios Ilustrados de la Historiografía Literaria Española: Miradas sobre la Edad Media y el Siglo de Oro (1700-1833). San Millán de la Cogolla: Centro Internacional de Investigación de la Lengua Española (CILengua), pp. 27-66.

Cañas Murillo, Jesús (2021). «Juan de la Cueva en los inicios científicos de la historiografía literaria española (1700-1857)». En Miguel Ángel Teijeiro Fuentes y José Roso Díaz (eds.), El teatro renacentista entre el Viejo y el Nuevo Mundo. Estudios dedicados a la Profesora Mercedes de los Reyes Peña. Cáceres: Universidad de Extremadura.

Cañas Murillo, Jesús y José Roso Díaz (eds.) (2019). En los inicios Ilustrados de la Historiografia Literaria Española: Miradas sobre la Edad Media y el Siglo De Oro (1700-1833). San Millán de la Cogolla: Centro Internacional de Investigación de la Lengua Española (CILengua).

Castro, Américo y Hugo A. Rennert (1919). Vida de Lope de Vega (1562-1635). Madrid: Imprenta de los Sucesores de Hernando [Publicada posteriormente, con notas adicionales de Fernando Lázaro Carreter, en 1968. Salamanca: Anaya].

Froldi, Rinaldo (1962). Il teatro valenzano e l'origine della commedia barocca. Pisa: Instituto di Letteratura Spagnola e Ispano-Americana dell'Università di Pisa.

LóPEZ MARTín, Ismael (2019). «Los tratados de poética del siglo XVIII y el tratamiento de dos figuras clave en el barroco español: Lope de Vega y Calderón de la Barca». En Jesús Cañas Murillo y José Roso Díaz (eds.), En los inicios Ilustrados de la Historiografia Literaria Española: Miradas sobre la Edad Media y el Siglo de Oro (1700-1833). San Millán de la Cogolla: Centro Internacional de Investigación de la Lengua Española (CILengua), pp. 305-321.

MenÉndez Pelayo, Marcelino (1919-1927). Estudios sobre el teatro de Lope de Vega. Madrid: Librería de Victoriano Suárez.

Montesinos, José F. (1951). Estudios sobre Lope de Vega. Ciudad de México: El Colegio de México.

Rennert, Hugo A. (1904). The life of Lope de Vega (1562-1635). Glasgow: The Glasgow University Press. 
Rozas, Juan Manuel (1982). Lope de Vega y Felipe IV en el «ciclo de senectute». Discurso en la solemne apertura del curso académico 1982-1983. Badajoz / Cáceres: Universidad de Extremadura.

Tomillo, Atanasio y Cristóbal Pérez Pastor (1901). Proceso de Lope de Vega por libelos contra unos cómicos. Madrid: Establecimiento Tipográfico de Fortanet.

VossLer, Karl (1932). Lope de Vega und sein Zeitalter. Munich: Beck.

Recibido: 21/05/2021

Aceptado: 05/07/2021 


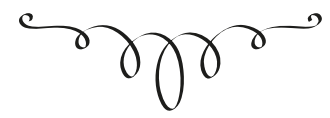

\section{LOPE DE VEGA SEGÚN LOS INICIADORES CIENTÍFICOS DE LA HISTORIOGRAFÍA LITERARIA ESPAÑOLA (1700-1850)}

RESUMEN: En este artículo se investiga sobre la visión que los primeros historiadores científicos de la literatura española transmiten a la historiografía y a la crítica de épocas posteriores a la suya, sobre la figura y la producción escrita de Félix Lope de Vega Carpio, el llamado, desde el momento en que le tocó vivir, «Monstruo de la Naturaleza»y «Fénix de los Ingenios». Se muestran las semejanzas y diferencias existentes en unos y otros, en sus obras dedicadas a trabajar sobre esos asuntos. Se han utilizado treinta y seis volúmenes que sirven como testimonio de las ideas aportadas, las opiniones y juicios críticos manifestados y las noticias recogidas sobre estos asuntos. Con ello hemos querido poner de manifiesto cuáles han sido las aportaciones legadas a la posteridad por los primeros historiadores científicos de la literatura española que publican sus trabajos en la Ilustración y en la primera mitad del siglo XIX.

PALABRAS CLAVE: Historiografía literaria, siglos XVIII y XIX españoles, biografía y producción literaria, Lope de Vega.

LOPE DE VEGA ACCORDING TO THE SCIENTIFIC INITIATOR of Spanish Literary Historiography (1700-1850)

AвSTRACT: This article investigates the vision that the first scientific historians of Spanish literature transmitted to historiography and criticism of later periods about the figure and written production of Félix Lope de Vega Carpio, the so-called «Monstruo de la Naturaleza» and «Fénix de los Ingenios» from the time he lived. The similarities and differences between the two are shown in their works dedicated to working on these subjects. Thirty-six volumes have been used as a testimony of the ideas contributed, the opinions and critical judgements expressed and the news collected on these matters. In doing so, we have sought to highlight the contributions bequeathed to posterity by the first scientific historians of Spanish Literature who published their works in the Enlightenment and in the first half of the 19th century.

KeYwords: Literary Historiography, Spanish 18th and 19th centuries, biography and literary production, Lope de Vega. 